\title{
Hydrosilylation of an Iron(IV) Nitride
}

\section{Complex}

Juan A. Valdez-Moreira, Sean P. Millikan, Xinfeng Gao, Veronica Carta, Chun-Hsing Chen and Jeremy M. Smith*

Department of Chemistry

Indiana University

800 E. Kirkwood Ave., Bloomington IN 47405, USA

smith962@indiana.edu 


\section{Contents}

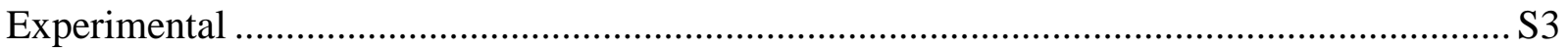

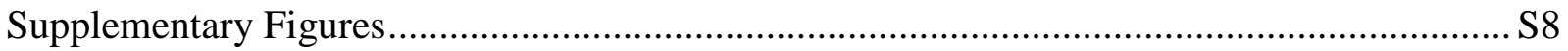

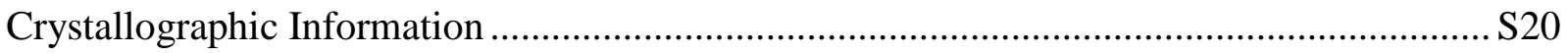

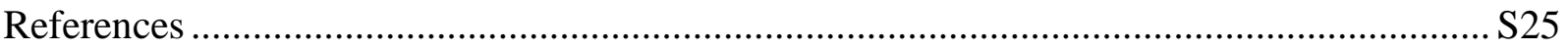




\section{Experimental}

General considerations. All manipulations involving air- or moisture sensitive compounds and their preparation were performed under an inert atmosphere of dry $\mathrm{N}_{2}$ by standard Schlenk techniques or in an M. Braun glovebox. Glassware used was oven dried for at least $12 \mathrm{~h}$ at $140{ }^{\circ} \mathrm{C}$ before use. Celite was oven dried for $12 \mathrm{~h}$ at $140{ }^{\circ} \mathrm{C}$. All solvents were purchased from SigmaAldrich, and used after being dried using alumina and Q5 drying columns. The compounds $\mathrm{PhB}(\mathrm{MesIm})_{3} \mathrm{Fe} \equiv \mathrm{N}^{1}, \mathrm{PhB}(\mathrm{MesIm})_{3} \mathrm{FeCl}^{2}$, and $\mathrm{LiNHtBu}^{3}$ were prepared according to literature procedures. All other chemicals were purchased from commercial vendors, and used as received. Deuterated solvents were purchased from Cambridge isotope labs. $\mathrm{C}_{6} \mathrm{D}_{6}$ and THF- $d_{8}$ were degassed and stored over molecular sieves for at least one day before use.

${ }^{1} \mathrm{H}$ NMR spectroscopic measurements of air and moisture sensitive compounds were made in JYoung NMR tubes, with the spectroscopic data recorded on Varian $400 \mathrm{MHz}$ NMR spectrometers at $25^{\circ} \mathrm{C}$. IR spectra were recorded with a Perkin Elmer spectrophotometer.

The Mössbauer spectrum was recorded on a SEE Co spectrometer. The sample temperature was controlled using a SVT-400 Dewar from Janis equipped with a Lake Shore 255 Temperature Controller. The isomer shifts are reported relative to the centroid of the spectrum of $\alpha-\mathrm{Fe}$ at 298 K. The sample was prepared by grinding spectroscopically pure material into a fine powder and adding it to a polyethylene cup $\left(1 \mathrm{~cm}^{2}\right)$ and squeezing another holder with a slightly smaller diameter that had been wrapped with Teflon tape. Data analysis was performed using the program $\mathrm{WMOSS}^{4}$ and quadrupole doublets were fitted to Lorentzian lineshapes. 
Preparation of PhB(MesIm) $)_{3} \mathrm{FeNH}^{\mathrm{t} B u}$. In a $20 \mathrm{~mL}$ scintillation vial, $\mathrm{PhB}(\mathrm{MesIm})_{3} \mathrm{FeCl}(610$ $\mathrm{mg}, 0.83 \mathrm{mmol})$ was suspended in diethyl ether $(4 \mathrm{~mL})$. Solid LiNH $\mathrm{Bu}(197 \mathrm{mg}, 2.49 \mathrm{mmol})$ was added to the stirring suspension. The reaction mixture was allowed to stir for $48 \mathrm{~h}$ at room temperature. The solvent was then evaporated under vacuum and extracted into pentane. The resulting solution was filtered through celite and concentrated under vacuum. The concentrated solution was stored at $-35{ }^{\circ} \mathrm{C}$ to obtain a yellow crystalline solid (253 mg 37\% yield). The connectivity of the complex was confirmed by single crystal X-ray diffraction (Fig. S2). ${ }^{1} \mathrm{H}$ NMR $\left(\mathrm{C}_{6} \mathrm{D}_{6}, 400 \mathrm{MHz}\right) \delta(\mathrm{ppm}) 87.5\left(9 \mathrm{H}, \mathrm{N}^{\mathrm{t}} \mathrm{Bu} \mathrm{C}\left(\mathrm{CH}_{3}\right)_{3}\right), 72.0(3 \mathrm{H}, \mathrm{Im}-\mathrm{H}), 65.0(3 \mathrm{H}, \mathrm{Im}-\mathrm{H}), 44.4(2 \mathrm{H}$, $\left.\mathrm{B}\left(\mathrm{C}_{6} \mathrm{H}_{5}\right) m / o-\mathrm{H}\right), 22.2\left(2 \mathrm{H}, \mathrm{B}\left(\mathrm{C}_{6} \mathrm{H}_{5}\right) m / o-\mathrm{H}\right), 19.1\left(1 \mathrm{H},\left(\mathrm{C}_{6} \mathrm{H}_{5}\right) p-\mathrm{H}\right), 2.63\left(9 \mathrm{H}, \mathrm{Mes} p-\mathrm{CH}_{3}\right),-1.64$ $(6 \mathrm{H}$, Mes $m-\mathrm{H}),-37.3\left(18 \mathrm{H}\right.$, Mes $\left.o-\mathrm{CH}_{3}\right)$. Anal. Calcd. for $\mathrm{C}_{46} \mathrm{H}_{54} \mathrm{BFeN}_{7} \bullet\left[(\mathrm{LiCl})\left(\mathrm{C}_{4} \mathrm{H}_{10} \mathrm{O}\right)_{2}\right]_{0.5}: \mathrm{C}$ 69.27, H 7.44, N 11.31; Found: C 69.74, H 7.31, N 11.27.

Preparation of PhB(MesIm) ${ }_{3} \mathrm{FeH}_{3} \mathrm{SiHPh}$ (1). In a $20 \mathrm{~mL}$ scintillation vial, $\mathrm{PhB}(\mathrm{Mes} I m)_{3} \mathrm{Fe} \equiv \mathrm{N}$ (250 mg, $0.350 \mathrm{mmol})$ was dissolved in THF ( $5 \mathrm{~mL})$. Phenylsilane $(0.43 \mathrm{~mL}, 3.5 \mathrm{mmol})$ was added to the stirring solution. The reaction mixture was stirred at room temperature for $1 \mathrm{~h}$, and the solvent was evaporated under vacuum. The solid was then redissolved in THF $(1 \mathrm{~mL})$ and layered with hexamethyldisiloxane and store at $-35{ }^{\circ} \mathrm{C}$ to yield orange crystals $(212 \mathrm{mg}, 75 \%$ yield $) .{ }^{1} \mathrm{H}$ NMR (THF-d $8,400 \mathrm{MHz}) \delta(\mathrm{ppm}) 8.27\left(\mathrm{~d}, 2 \mathrm{H}, \mathrm{B}\left(\mathrm{C}_{6} \mathrm{H}_{5}\right) o-\mathrm{H}\right), 7.57\left(\mathrm{t}, 2 \mathrm{H}, \mathrm{B}\left(\mathrm{C}_{6} \mathrm{H}_{5}\right) m-\mathrm{H}\right), 7.45(\mathrm{t}$, 1H, B( $\left.\left.\mathrm{C}_{6} \mathrm{H}_{5}\right) p-\mathrm{H}\right), 7.25(\mathrm{~s}, 3 \mathrm{H}, \mathrm{Im}-\mathrm{H}), 7.11\left(\mathrm{t}, 1 \mathrm{H}, \mathrm{Si}\left(\mathrm{C}_{6} \mathrm{H}_{5}\right) p-\mathrm{H}\right), 6.92\left(\mathrm{t}, 2 \mathrm{H}, \mathrm{Si}\left(\mathrm{C}_{6} \mathrm{H}_{5}\right) m-\mathrm{H}\right)$, 6.59 (s, 6H, Mes $m$-H overlapped with Im-H), 6.59 (s, 3H, Im-H overlapped with Mes $m-\mathrm{H}$ ), 6.50 (d, $\left.2 \mathrm{H}, \mathrm{Si}\left(\mathrm{C}_{6} \mathrm{H}_{5}\right) o-\mathrm{H}\right), 2.05\left(\mathrm{~s}, 9 \mathrm{H}, \mathrm{Mes} p-\mathrm{CH}_{3}\right), 1.81$ (s, 18H, Mes $\left.o-\mathrm{CH}_{3}\right),-12.90$ (s, 3H, Si/Fe$\left.\mathrm{H},{ }^{1} J_{\mathrm{Si}-\mathrm{H}}=77 \mathrm{~Hz}\right) .{ }^{29} \mathrm{Si}\left\{{ }^{1} \mathrm{H}\right\} \mathrm{NMR}\left(99 \mathrm{MHz}, \mathrm{THF}-d_{8}\right) \delta 89.87 . \mathrm{IR}(\mathrm{KBr}): v_{\mathrm{Si}-\mathrm{H}}=2121 \mathrm{~cm}^{-1}$. Due to the high solubility of the reaction byproduct(s), we were unable to isolate this complex in sufficient 
purity for elemental analysis. In addition, we could not obtain reliable mass spectrometry data for this complex, possibly due to the presence of the reaction byproduct(s).

Preparation of $\mathbf{P h B}(\text { MesIm) })_{3} \mathrm{FeNHSiHPh}_{2}$ (2). In a $20 \mathrm{~mL}$ scintillation vial, $\mathrm{PhB}(\mathrm{Mes} I m)_{3} \mathrm{Fe} \equiv \mathrm{N}$ (196 mg, $0.274 \mathrm{mmol}$ ) was dissolved in THF (5 mL). Diphenylsilane (51 $\mu \mathrm{L}, 0.274 \mathrm{mmol})$ was added to the stirring solution. The reaction mixture was then stirred at room temperature overnight, and the solvent was evaporated under vacuum to obtain a tan solid .Crystals suitable for X-ray diffraction were grown by layering $n$-pentane onto a THF solution $(1 \mathrm{~mL})$ and stored at $-35{ }^{\circ} \mathrm{C}$, yielding off-white crystals (173 mg, 70\% yield). ${ }^{1} \mathrm{H}$ NMR $\left(\mathrm{C}_{6} \mathrm{D}_{6}, 400 \mathrm{MHz}\right) \delta(\mathrm{ppm}) 70.8(3 \mathrm{H}$, Im-H), $67.9(3 \mathrm{H}, \mathrm{Im}-\mathrm{H}), 44.5\left(2 \mathrm{H}, \mathrm{B}\left(\mathrm{C}_{6} \mathrm{H}_{5}\right) \mathrm{m} / \mathrm{o}-\mathrm{H}\right), 39.3\left(4 \mathrm{H}, \mathrm{Si}\left(\mathrm{C}_{6} \mathrm{H}_{5}\right)_{2} \mathrm{~m} / o-\mathrm{H}\right), 22.2(2 \mathrm{H}$, $\left.\mathrm{B}\left(\mathrm{C}_{6} \mathrm{H}_{5}\right) m / o-\mathrm{H}\right), 19.2\left(1 \mathrm{H},\left(\mathrm{C}_{6} \mathrm{H}_{5}\right) p-\mathrm{H}\right), 16.8\left(4 \mathrm{H}, \mathrm{Si}\left(\mathrm{C}_{6} \mathrm{H}_{5}\right)_{2} m / o-\mathrm{H}\right), 13.0\left(2 \mathrm{H}, \mathrm{Si}\left(\mathrm{C}_{6} \mathrm{H}_{5}\right)_{2} p-\mathrm{H}\right)$, $2.6\left(9 \mathrm{H}\right.$, Mes $\left.p-\mathrm{CH}_{3}\right),-1.4(6 \mathrm{H}$, Mes $m-\mathrm{H}),-37.7\left(18 \mathrm{H}\right.$, Mes $\left.o-\mathrm{CH}_{3}\right) . \mu_{\text {eff }}\left(\right.$ Evans', $\left.\mathrm{C}_{6} \mathrm{D}_{6}, 298 \mathrm{~K}\right)$ : 4.7 BM. APCI-MS: m/z [M] $]^{+}$Calcd for $\mathrm{C}_{54} \mathrm{H}_{57} \mathrm{BFeN}_{7} \mathrm{SiO} 914.3841$; Found $914.3864(\mathrm{M}+\mathrm{OH})^{+}$.

\section{Preparation of $\mathrm{PhB}(\mathrm{MesIm})_{3} \mathrm{FeH}_{3} \mathrm{SiPh}_{2}(3)$.}

From complex 2: In a $20 \mathrm{ml}$ scintillation vial, diphenylsilane $(0.26 \mathrm{~mL}, 1.387 \mathrm{mmol})$ was added to a stirring solution of $2(80 \mathrm{mg}, 0.09 \mathrm{mmol})$ in THF $(10 \mathrm{~mL})$. The mixture was stirred at room temperature for 4 days, and the solvent was removed under vacuum to yield a red oil. Crystals suitable for X-ray diffraction were grown by layering $n$-pentane onto a THF solution $(1 \mathrm{~mL})$ at room temperature ( $25 \mathrm{mg}, 31 \%$ yield)

From $P h B(\text { MesIm })_{3} F e \equiv N$ : In a $20 \mathrm{ml}$ scintillation vial, $\mathrm{PhB}(\mathrm{Mes} I m)_{3} \mathrm{Fe} \equiv \mathrm{N}(250 \mathrm{mg}, 0.350 \mathrm{mmol})$ was dissolved in diphenylsilane $(2 \mathrm{~mL}, 0.1 \mathrm{~mol})$. The mixture was stirred at room temperature overnight, and the solvent was removed under vacuum to yield an orange solid, which was crystallized using the same method as above (98 $\mathrm{mg}, 32 \%$ yield). 
From $\mathrm{PhB}(\mathrm{Mes} I m)_{3} \mathrm{FeNH}{ }^{t} \mathrm{Bu}$ : In a $20 \mathrm{ml}$ scintillation vial, diphenylsilane $(0.26 \mathrm{~mL}, 1.387 \mathrm{mmol})$ was added to a stirring solution $\mathrm{PhB}(\mathrm{MesIm})_{3} \mathrm{FeNH}^{\mathrm{t}} \mathrm{Bu}(107 \mathrm{mg}, 0.139 \mathrm{mmol})$ in THF (10 mL). An immediate color change from yellow/green to orange was observed upon addition. The mixture was stirred at room temperature for $1 \mathrm{~h}$, and the solvent was removed under vacuum to yield an orange solid. Crystals suitable for X-ray diffraction were grown by layering $n$-pentane onto a THF solution $(1 \mathrm{~mL})$ at room temperature $(53 \mathrm{mg}, 43 \%$ yield).

${ }^{1} \mathrm{H}$ NMR (THF-d $\left.8,400 \mathrm{MHz}\right) \delta(\mathrm{ppm}) 8.29\left(\mathrm{~d}, 2 \mathrm{H}, \mathrm{B}\left(\mathrm{C}_{6} \mathrm{H}_{5}\right) o-\mathrm{H}\right), 7.57\left(\mathrm{t}, 2 \mathrm{H}, \mathrm{B}\left(\mathrm{C}_{6} \mathrm{H}_{5}\right) m-\mathrm{H}\right), 7.46$ (t, 1H, B $\left.\left(\mathrm{C}_{6} \mathrm{H}_{5}\right) p-\mathrm{H}\right), 7.29(\mathrm{~s}, 3 \mathrm{H}, \mathrm{Im}-\mathrm{H}), 7.12\left(\mathrm{t}, 2 \mathrm{H}, \mathrm{Si}\left(\mathrm{C}_{6} \mathrm{H}_{5}\right)_{2} p-\mathrm{H}\right), 6.94\left(\mathrm{t}, 4 \mathrm{H}, \mathrm{Si}\left(\mathrm{C}_{6} \mathrm{H}_{5}\right)_{2} m-\right.$ H), $6.62\left(\mathrm{~d}, 4 \mathrm{H}, \mathrm{Si}\left(\mathrm{C}_{6} \mathrm{H}_{5}\right)_{2} o-\mathrm{H}\right), 6.59(\mathrm{~s}, 3 \mathrm{H}, \mathrm{Im}-\mathrm{H}), 6.41$ (s, 6H, Mes $\left.m-\mathrm{H}\right), 1.92$ (s, 9H, Mes $p$ $\left.\mathrm{CH}_{3}\right), 1.83\left(\mathrm{~s}, 18 \mathrm{H}\right.$, Mes $\left.o-\mathrm{CH}_{3}\right),-11.70\left(\mathrm{~s}, 3 \mathrm{H}, \mathrm{Si} / \mathrm{Fe}-\mathrm{H},{ }^{1} J_{\mathrm{Si}-\mathrm{H}}=77 \mathrm{~Hz}\right) .{ }^{29} \mathrm{Si}\left\{{ }^{1} \mathrm{H}\right.$ NMR $(99 \mathrm{MHz}$, THF- $\left.d_{8}\right) \delta$ 103.74. IR $(\mathrm{KBr}): v_{\mathrm{Si}-\mathrm{H}}=2069 \mathrm{~cm}^{-1}$ ESI-MS: $\mathrm{m} / \mathrm{z}[\mathrm{M}]^{+}$Calcd for $\mathrm{C}_{54} \mathrm{H}_{57} \mathrm{BFeN}_{6} \mathrm{Si}$ 884.3856; Found 884.3862.

Preparation of PhB(MesIm) ${ }_{3} \mathrm{FeH}_{3} \mathrm{SiPhNH}^{\mathrm{t} B u}$ (4). In a $20 \mathrm{~mL}$ scintillation vial, phenylsilane ( $60 \mu \mathrm{L}, 0.484 \mathrm{mmol})$ was added to a stirring solution of $\mathrm{PhB}(\mathrm{Mes} I m){ }_{3} \mathrm{FeNH} \mathrm{H}^{\mathrm{B}} \mathrm{Bu}(93.5 \mathrm{mg}, 0.121$ mmol) in THF $(10 \mathrm{~mL})$. A sudden solution color change from green/yellow to orange was observed upon addition of the silane. The solution was stirred at room temperature for $1 \mathrm{~h}$. Then the solvent was evaporated under vacuum to obtain an orange solid. Crystals suitable for X-ray diffraction were grown by layering hexamethyldisiloxane onto a THF solution $(1 \mathrm{~mL})$ and stored at $-35{ }^{\circ} \mathrm{C}$ overnight $\left(87 \mathrm{mg}, 82 \%\right.$ yield). ${ }^{1} \mathrm{H}$ NMR $\left(\mathrm{THF}-\mathrm{d}_{8}, 400 \mathrm{MHz}\right) \delta(\mathrm{ppm}) 8.25(\mathrm{~d}, 2 \mathrm{H}$, $\left.\mathrm{B}\left(\mathrm{C}_{6} \mathrm{H}_{5}\right) o-\mathrm{H}\right), 7.54\left(\mathrm{t}, 2 \mathrm{H}, \mathrm{B}\left(\mathrm{C}_{6} \mathrm{H}_{5}\right) m-\mathrm{H}\right), 7.43\left(\mathrm{t}, 1 \mathrm{H}, \mathrm{B}\left(\mathrm{C}_{6} \mathrm{H}_{5}\right) p-\mathrm{H}\right), 7.23(\mathrm{~s}, 3 \mathrm{H}, \mathrm{Im}-\mathrm{H}), 7.08(\mathrm{t}$, 1H, $\left.\mathrm{Si}\left(\mathrm{C}_{6} \mathrm{H}_{5}\right) p-\mathrm{H}\right), 6.91\left(\mathrm{t}, 2 \mathrm{H}, \mathrm{Si}\left(\mathrm{C}_{6} \mathrm{H}_{5}\right) m-\mathrm{H}\right), 6.69\left(\mathrm{~d}, 2 \mathrm{H}, \mathrm{Si}\left(\mathrm{C}_{6} \mathrm{H}_{5}\right) o-\mathrm{H}\right), 6.66(\mathrm{~s}, 6 \mathrm{H}$, Mes $m-$ H), 6.51 (s, 3H, Im-H), $2.16\left(\mathrm{~s}, 9 \mathrm{H}, \mathrm{Mes} p-\mathrm{CH}_{3}\right), 1.82$ (s, 18H, Mes $\left.o-\mathrm{CH}_{3}\right), 0.45$ (s, 9H, NtBu), - 
$13.04\left(\mathrm{~s}, 3 \mathrm{H}, \mathrm{Si} / \mathrm{Fe}-\mathrm{H},{ }^{1} J_{\mathrm{Si}-\mathrm{H}}=77 \mathrm{~Hz}\right) .{ }^{29} \mathrm{Si}\left\{{ }^{1} \mathrm{H}\right\} \mathrm{NMR}\left(99 \mathrm{MHz}, \mathrm{THF}-d_{8}\right) \delta 77.21 . \mathrm{IR}(\mathrm{KBr}): v_{\mathrm{Si}-\mathrm{H}}$ $=2091 \mathrm{~cm}^{-1}$ ESI-MS: $\mathrm{m} / \mathrm{z}[\mathrm{M}]^{+}$Calcd for $\mathrm{C}_{52} \mathrm{H}_{62} \mathrm{BFeN}_{7} \mathrm{Si}$ 879.4273; Found 879.4292 . 


\section{Supplementary Figures}

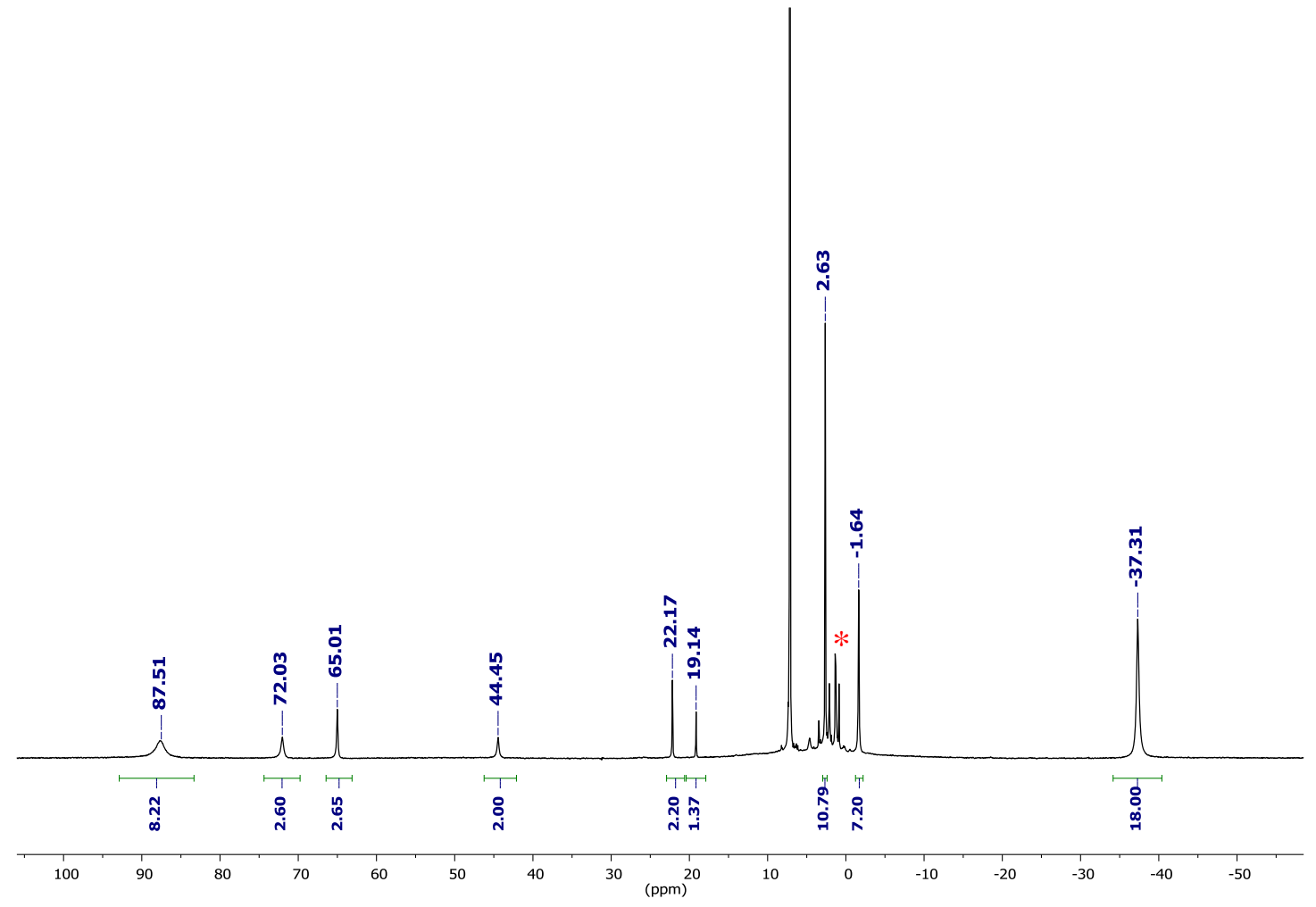

Figure S1. ${ }^{1} \mathrm{H}$ NMR $\left(400 \mathrm{MHz}, \mathrm{C}_{6} \mathrm{D}_{6}, 25{ }^{\circ} \mathrm{C}\right)$ of $\mathbf{P h B}(\mathbf{M e s I m}) 3 \mathbf{F e N H}{ }^{\mathrm{t} B u}$. The $(*)$ denotes peaks from the residual diethyl ether and pentane solvent

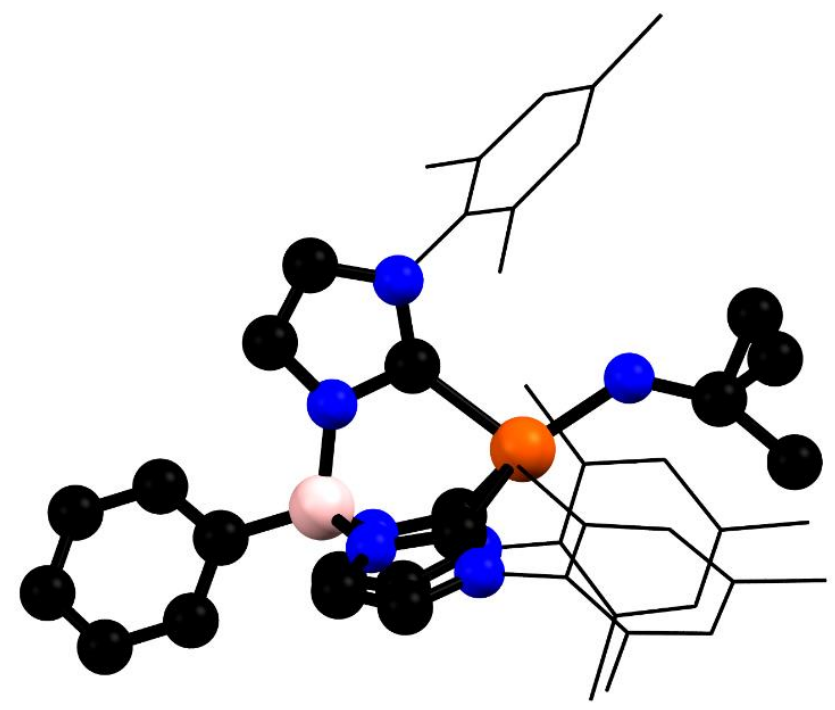

Figure S2. Ball and stick diagram showing the connectivity of $\mathbf{P h B}(\mathbf{M e s} \mathbf{I m})_{3} \mathbf{F e N H} \mathbf{H}^{\mathbf{t}} \mathbf{B u}$. Color scheme: C, black; N, blue; B, pink; Fe, orange. The Mesityl groups are shown with wireframe representation for clarity. 


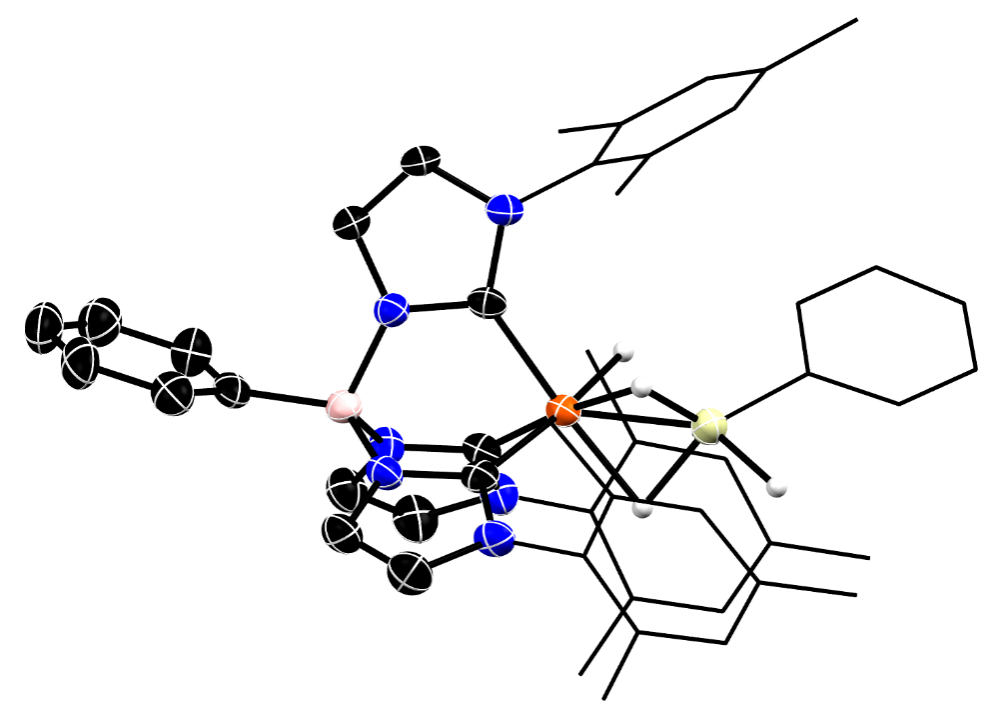

Figure S3. Molecular structure of 1. Thermal ellipsoids are shown at 50\% probability. Color scheme: C, black; N, blue; B, pink; Fe, orange; $\mathrm{Si}$, yellow. Most $\mathrm{H}$ atoms and solvent molecules have been omitted for clarity. The Mes and $\mathrm{Ph}$ groups are shown with wireframe representation for clarity.

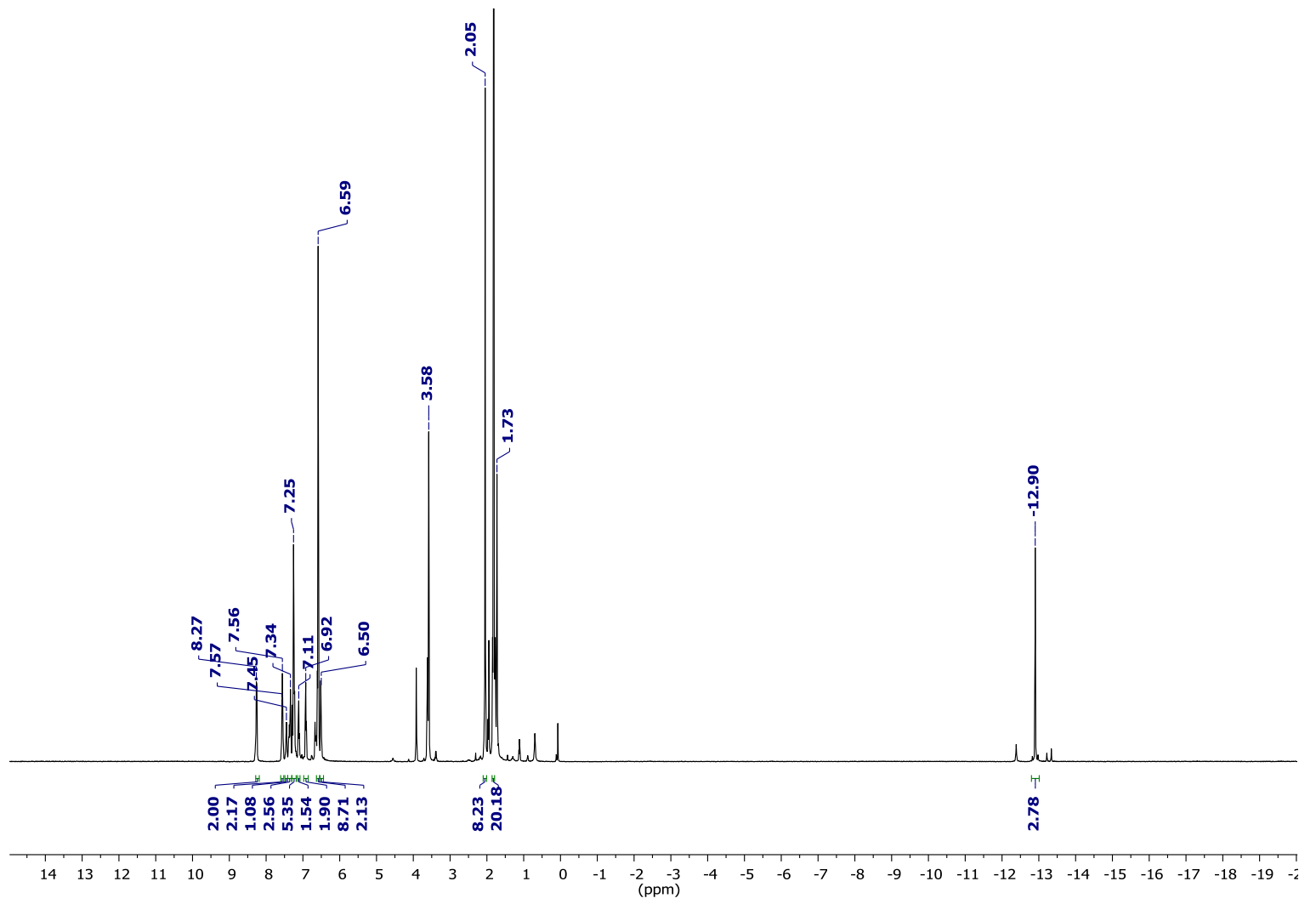

Figure S4. ${ }^{1} \mathrm{H}$ NMR $\left(400 \mathrm{MHz}, \mathrm{THF}-d_{8}, 25^{\circ} \mathrm{C}\right)$ of complex 1. 


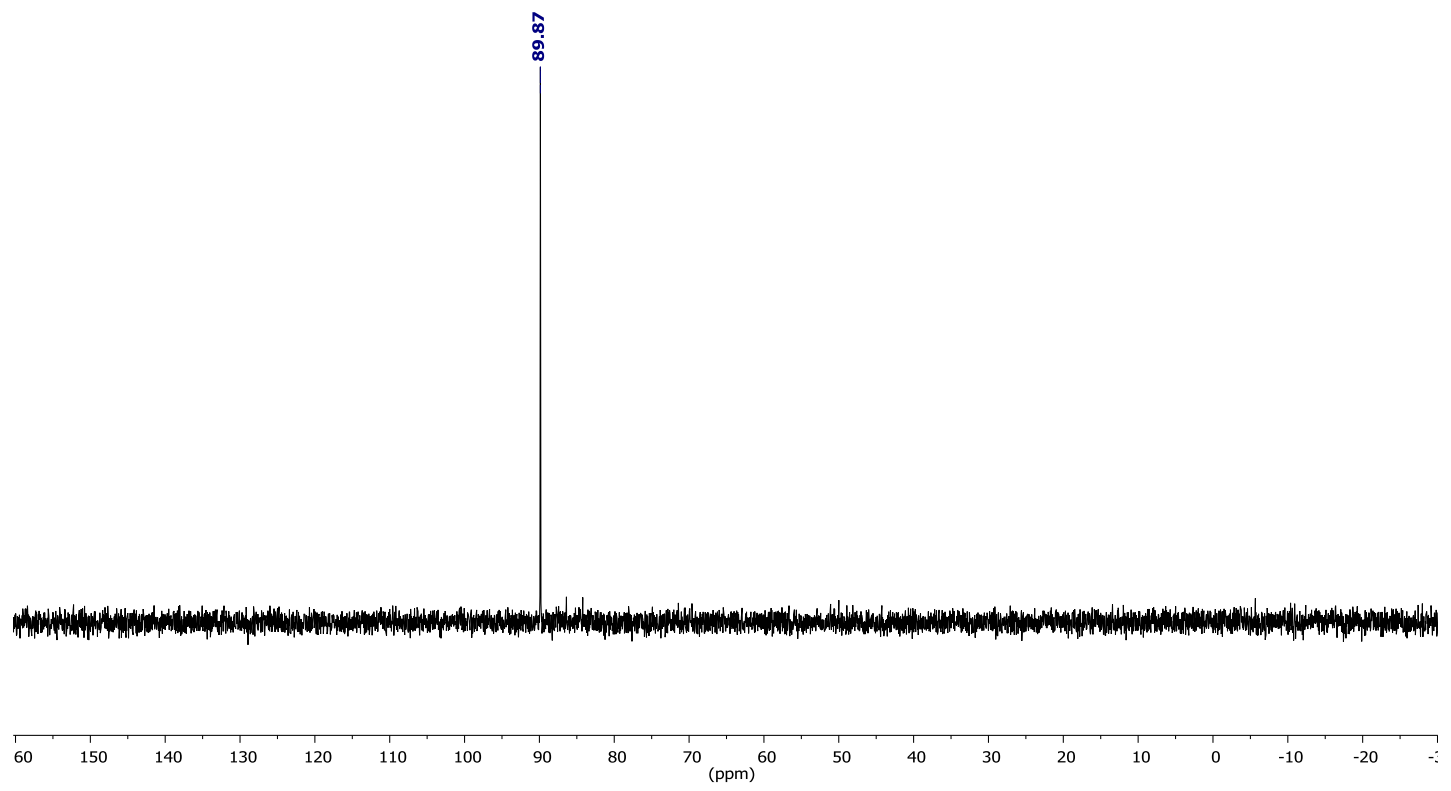

Figure S5. ${ }^{29} \mathrm{Si}\left\{{ }^{1} \mathrm{H}\right\}$ NMR $\left(99 \mathrm{MHz}, \mathrm{THF}-d 8,25{ }^{\circ} \mathrm{C}\right)$ of complex 1.

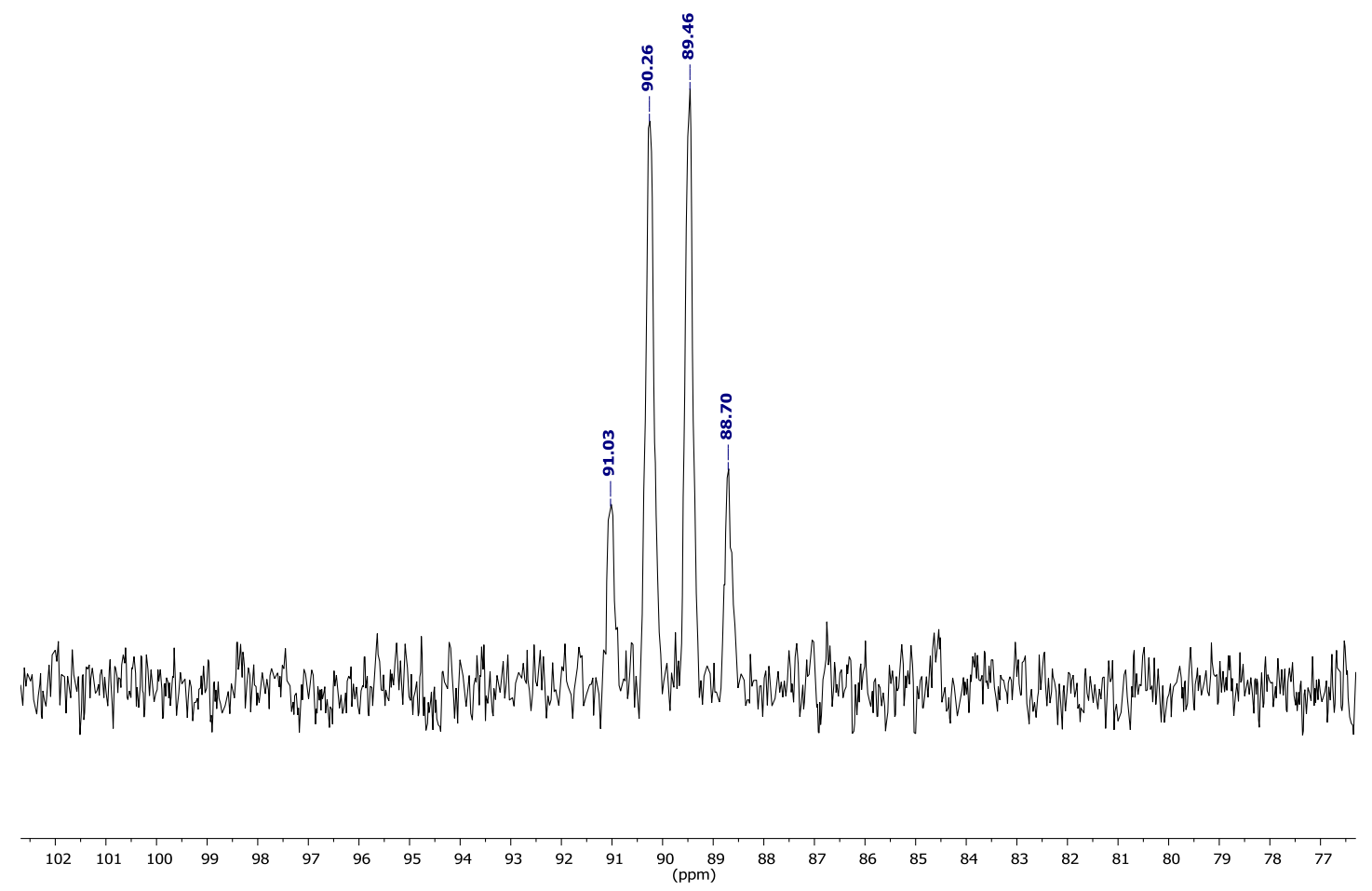

Figure S6. ${ }^{29} \mathrm{Si}$ NMR $\left(99 \mathrm{MHz}, \mathrm{THF}-d 8,25{ }^{\circ} \mathrm{C}\right)$ of complex $\mathbf{1}$. 


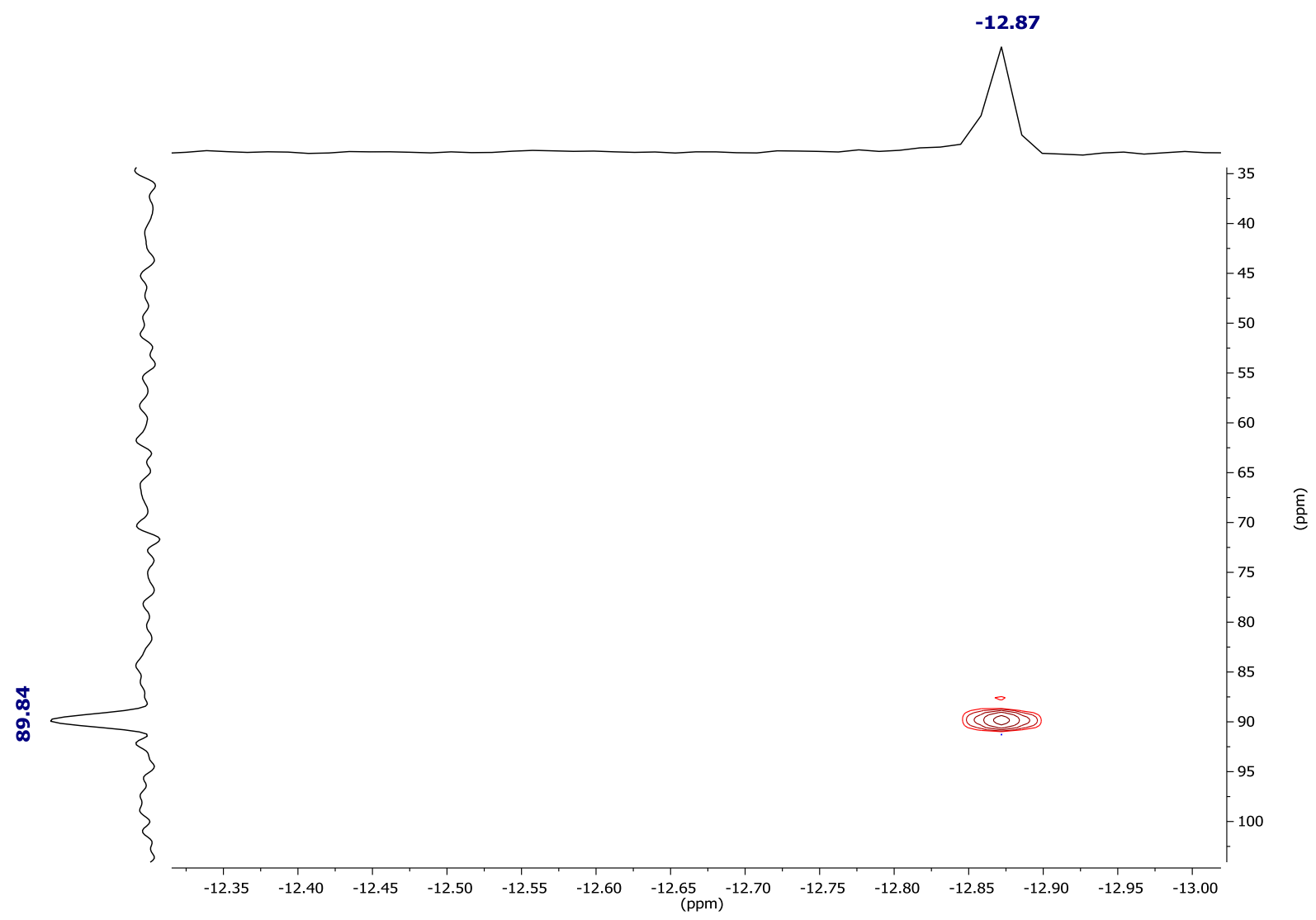

Figure S7. ${ }^{29} \mathrm{Si} /{ }^{1} \mathrm{H}$ HMQC $\left(99 \mathrm{MHz} / 500 \mathrm{MHz}, \mathrm{THF}-d 8,25{ }^{\circ} \mathrm{C}\right)$ of $\mathbf{1}$.

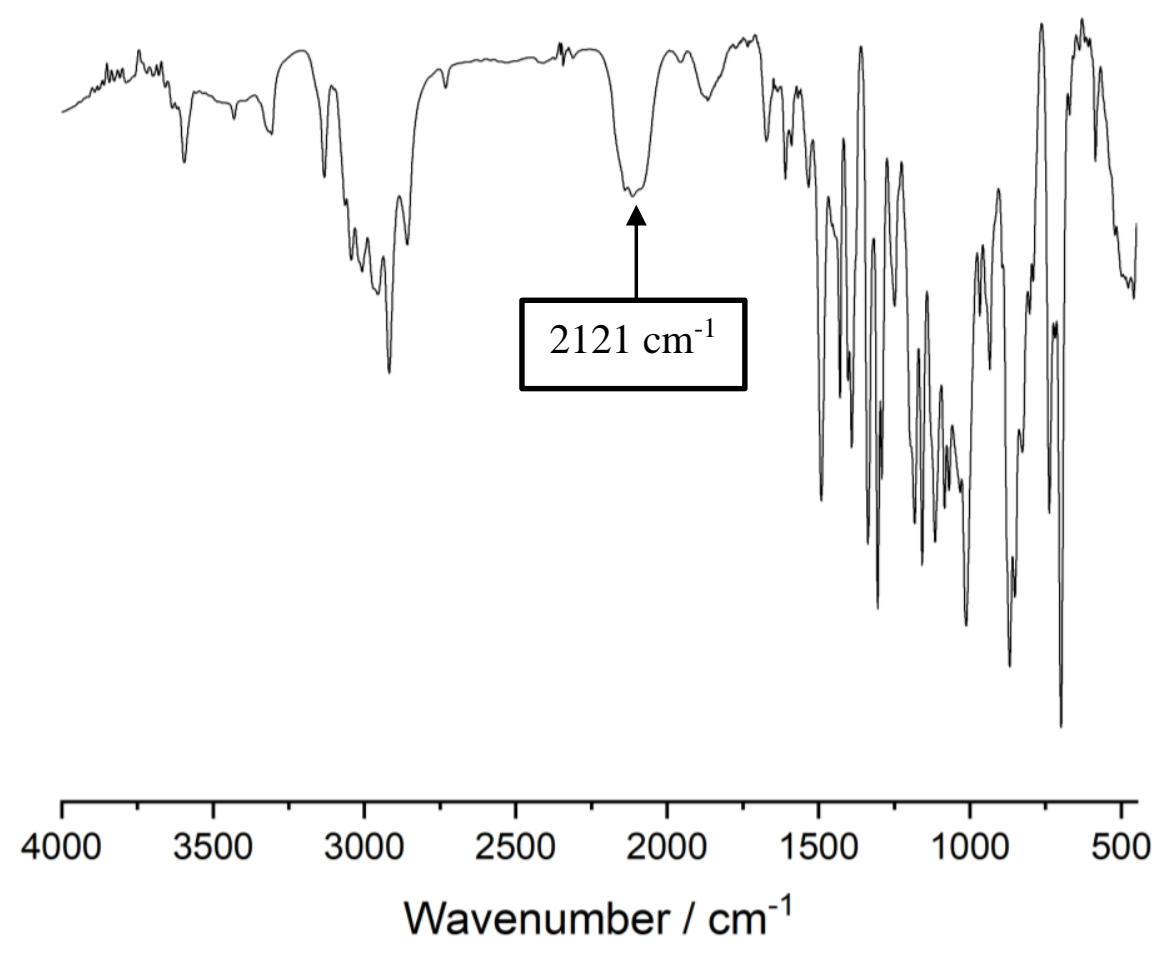

Figure S8. IR spectrum of 1 collected in $\mathrm{KBr}$ at $25{ }^{\circ} \mathrm{C}$. 


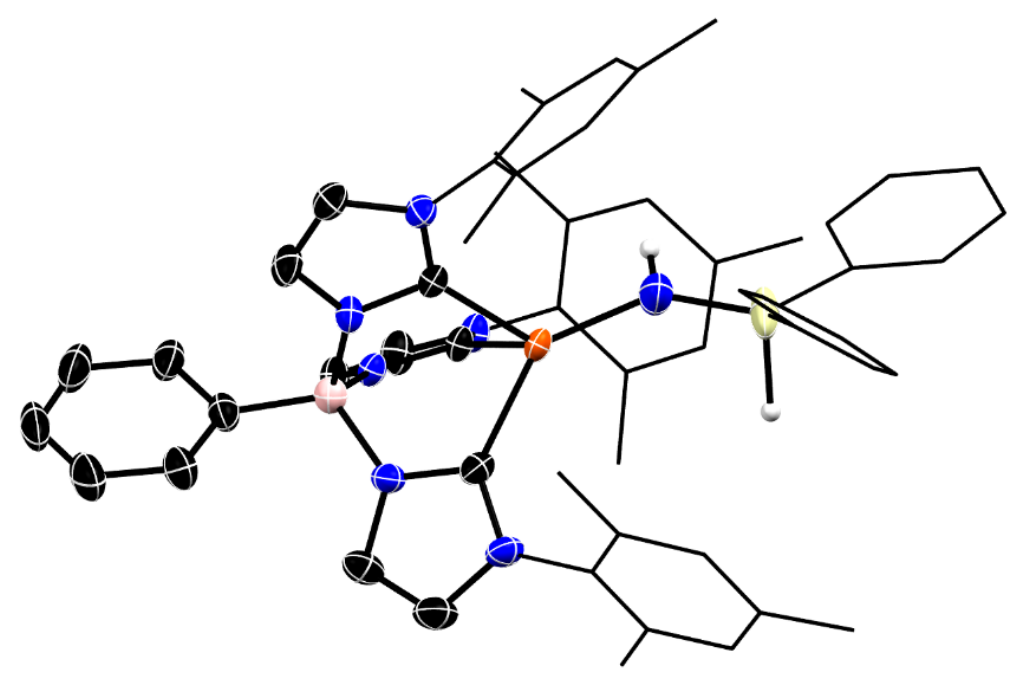

Figure S9. Molecular structure of 2. Thermal ellipsoids are shown at 50\% probability. Color scheme: C, black; N, blue; B, pink; Fe, orange; Si, yellow. Most $\mathrm{H}$ atoms and solvent molecules have been omitted for clarity. The Mes and $\mathrm{Ph}$ groups are shown with wireframe representation for clarity.

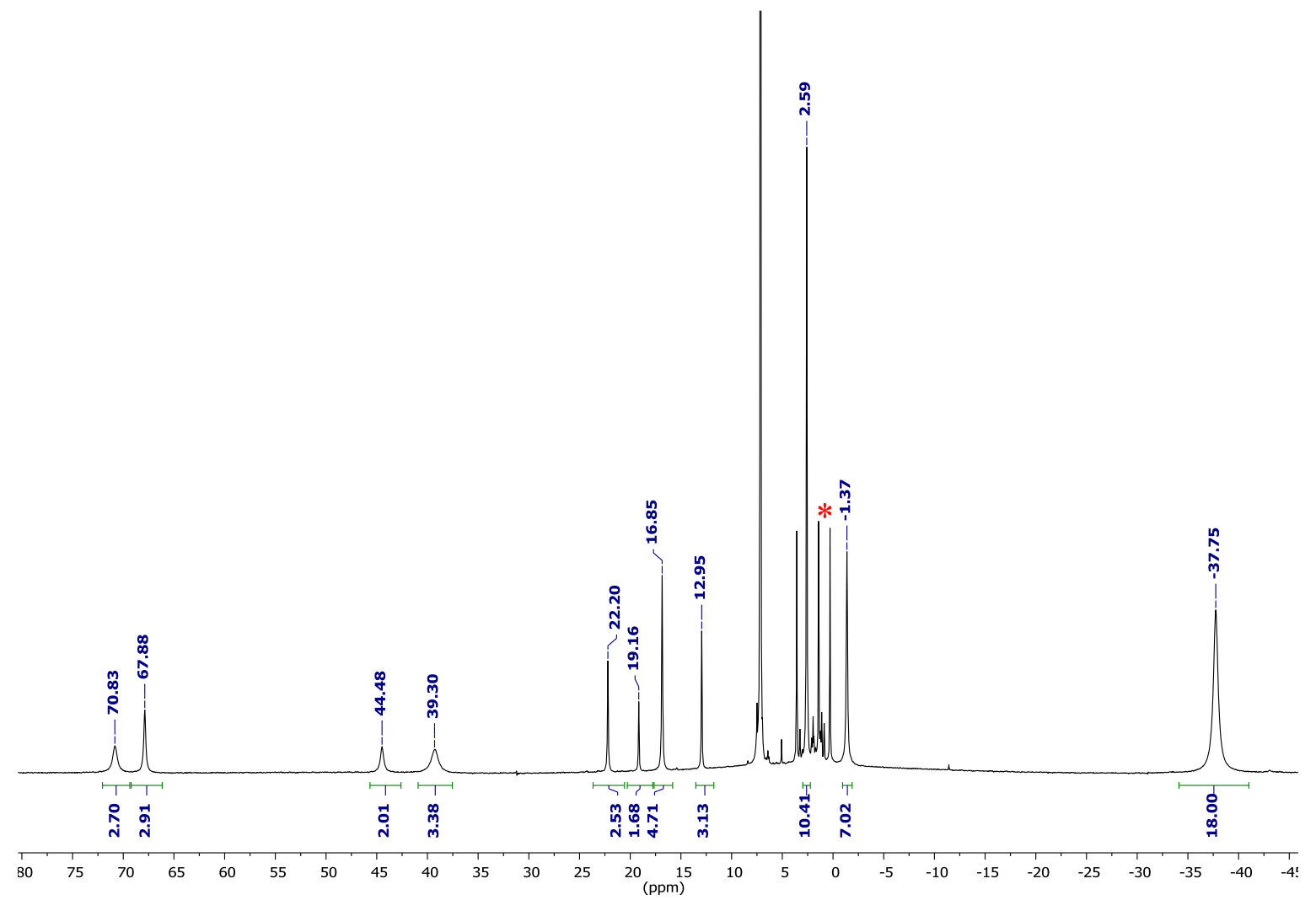

Figure S10. ${ }^{1} \mathrm{H}$ NMR $\left(400 \mathrm{MHz}, \mathrm{C}_{6} \mathrm{D}_{6}, 25^{\circ} \mathrm{C}\right)$ of 2 . The $(*)$ denotes peaks from the residual THF solvent and silicon grease. 


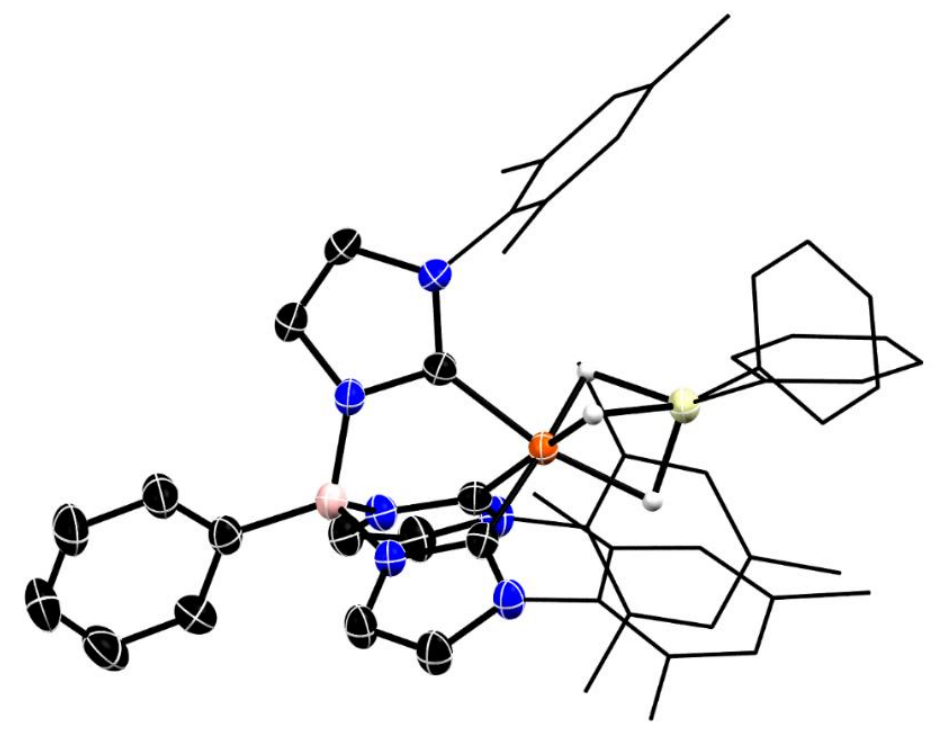

Figure S11. Molecular structure of 3. Thermal ellipsoids are shown at 50\% probability. Color scheme: C, black; N, blue; B, pink; Fe, orange; Si, yellow. Most $\mathrm{H}$ atoms and solvent molecules have been omitted for clarity. The Mes and $\mathrm{Ph}$ groups are shown with wireframe representation for clarity.

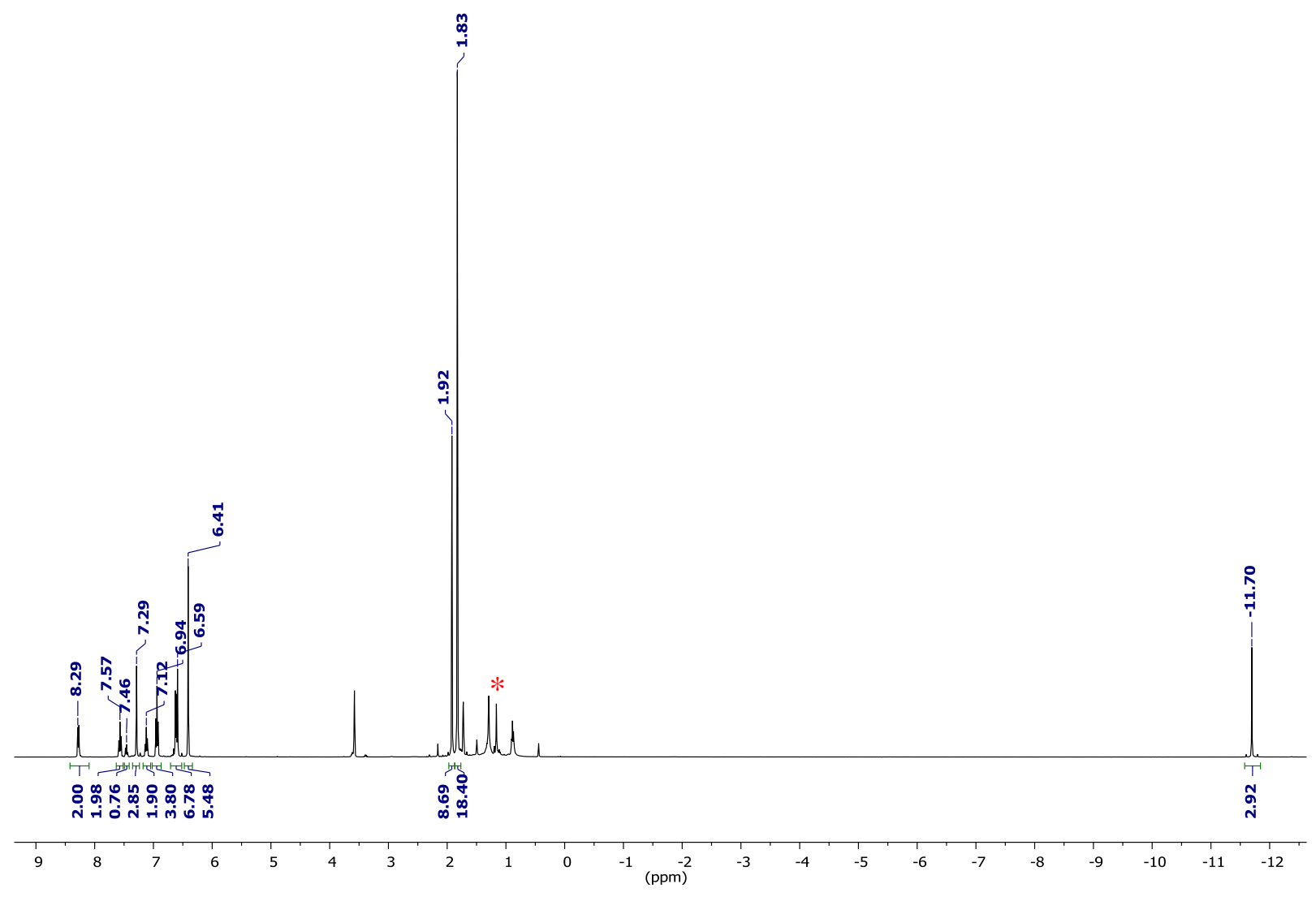

Figure S12. ${ }^{1} \mathrm{H}$ NMR $\left(400 \mathrm{MHz}, \mathrm{THF}-d_{8}, 25{ }^{\circ} \mathrm{C}\right)$ of complex 3. The $(*)$ denotes peaks from the residual diethyl ether and pentane solvent. 


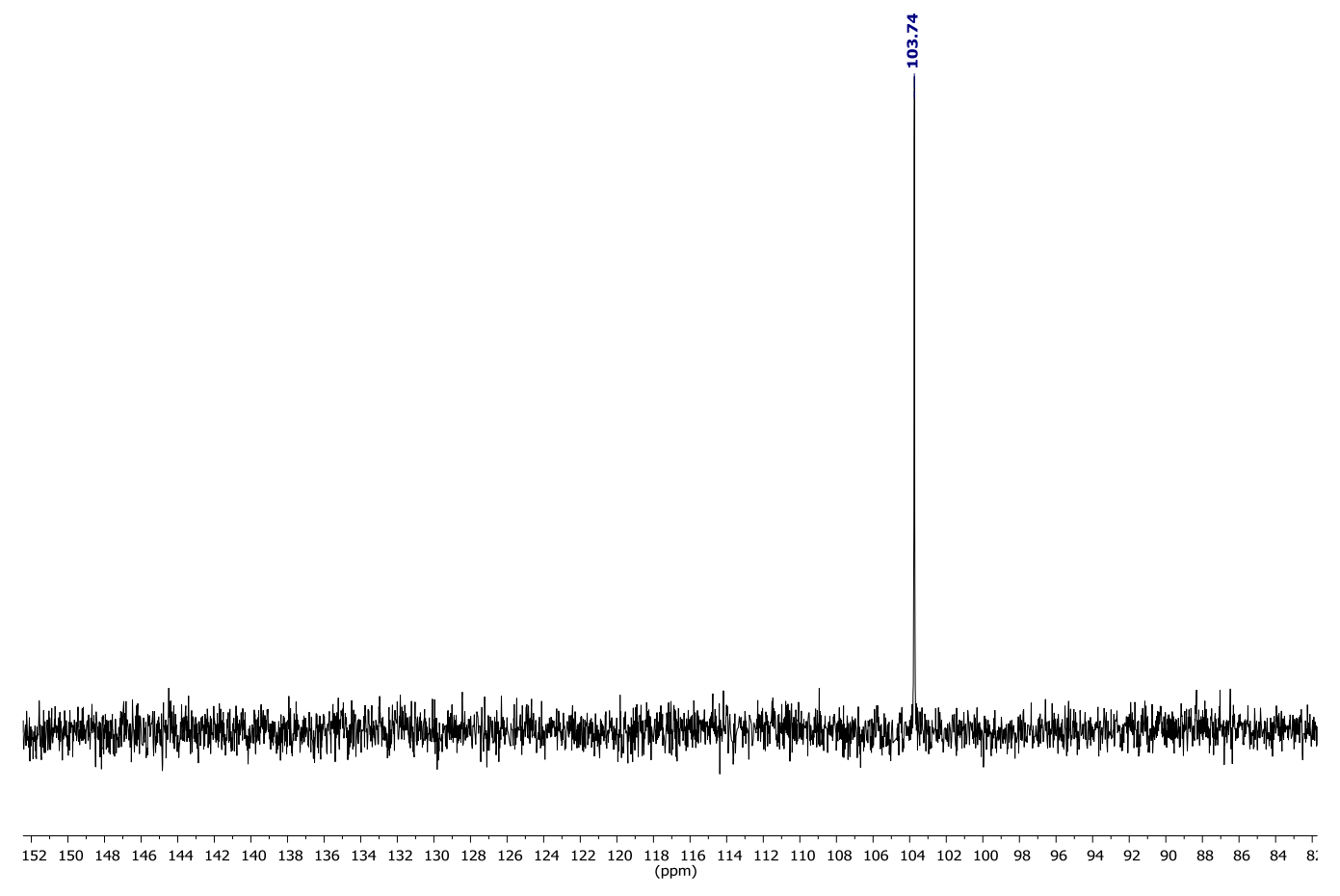

Figure S13. ${ }^{29} \mathrm{Si}\left\{{ }^{1} \mathrm{H}\right\}$ NMR $\left(99 \mathrm{MHz}, \mathrm{THF}-d_{8}, 25{ }^{\circ} \mathrm{C}\right)$ of complex 3.

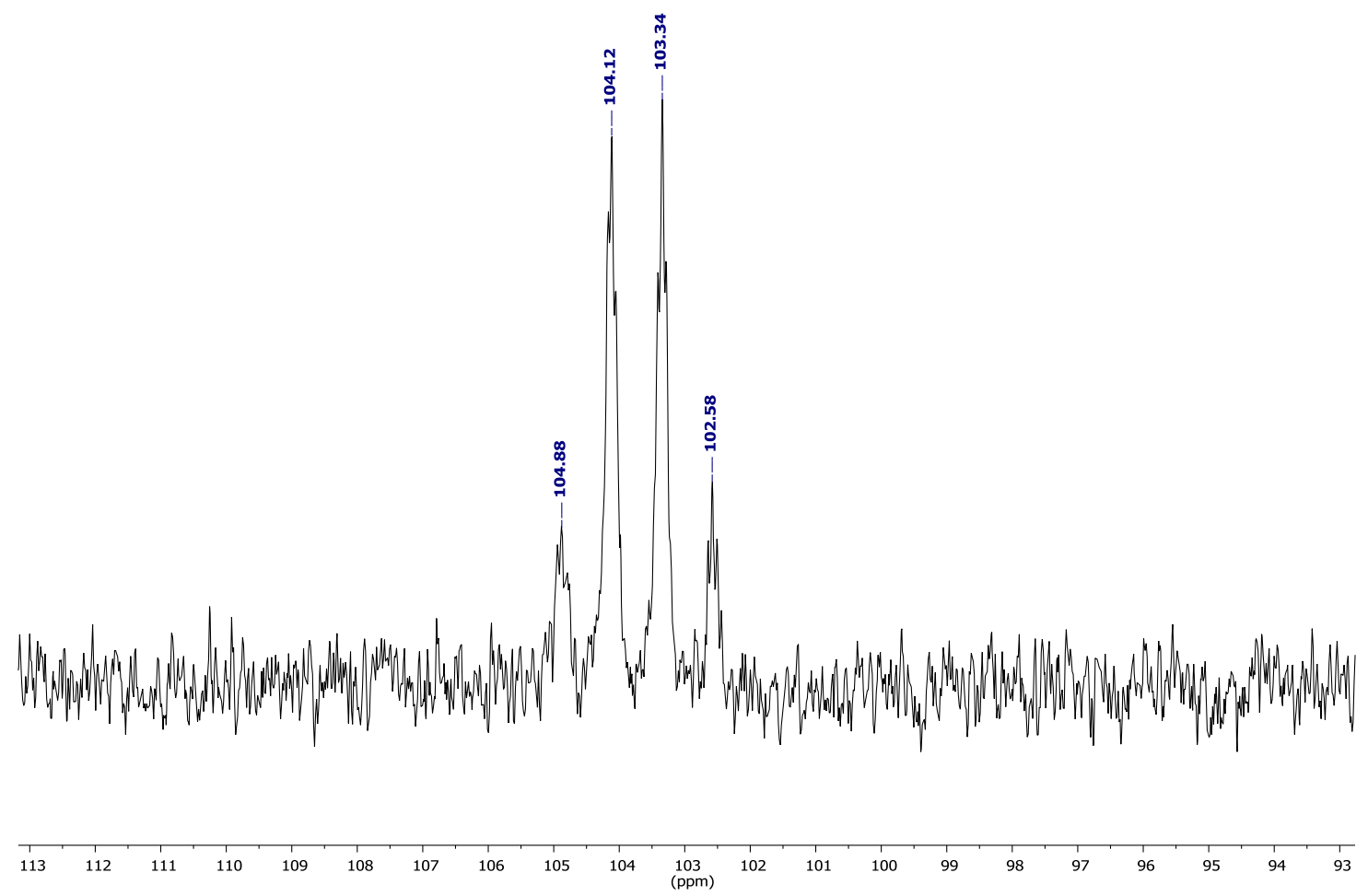

Figure S14. ${ }^{29} \mathrm{Si}$ NMR (99 MHz, THF- $\left.d_{8}, 25{ }^{\circ} \mathrm{C}\right)$ of complex of 3. 


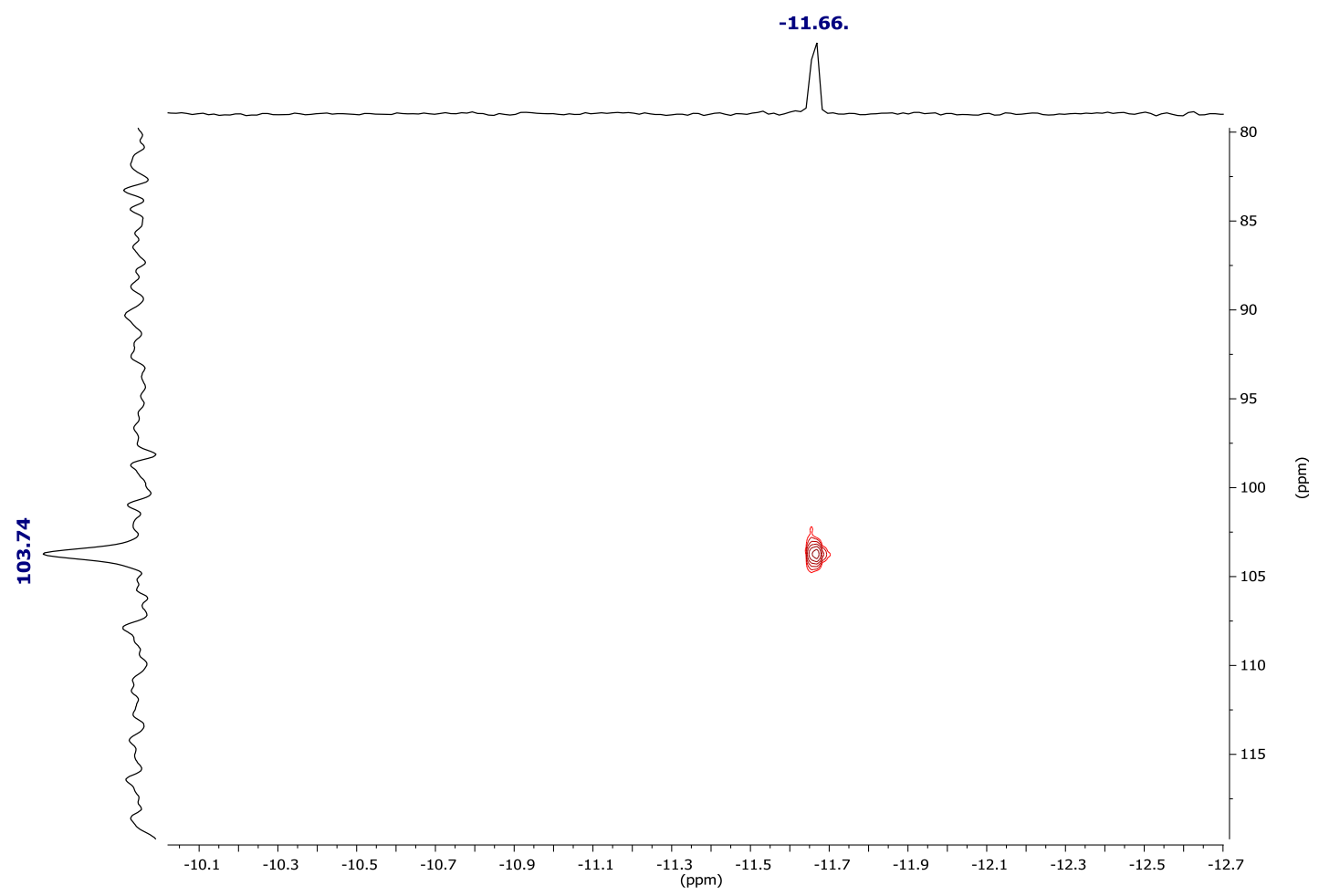

Figure S15. ${ }^{29} \mathrm{Si} /{ }^{1} \mathrm{H}$ HMQC $\left(99 \mathrm{MHz} / 500 \mathrm{MHz}, \mathrm{THF}-d_{8}, 25{ }^{\circ} \mathrm{C}\right)$ of 3.

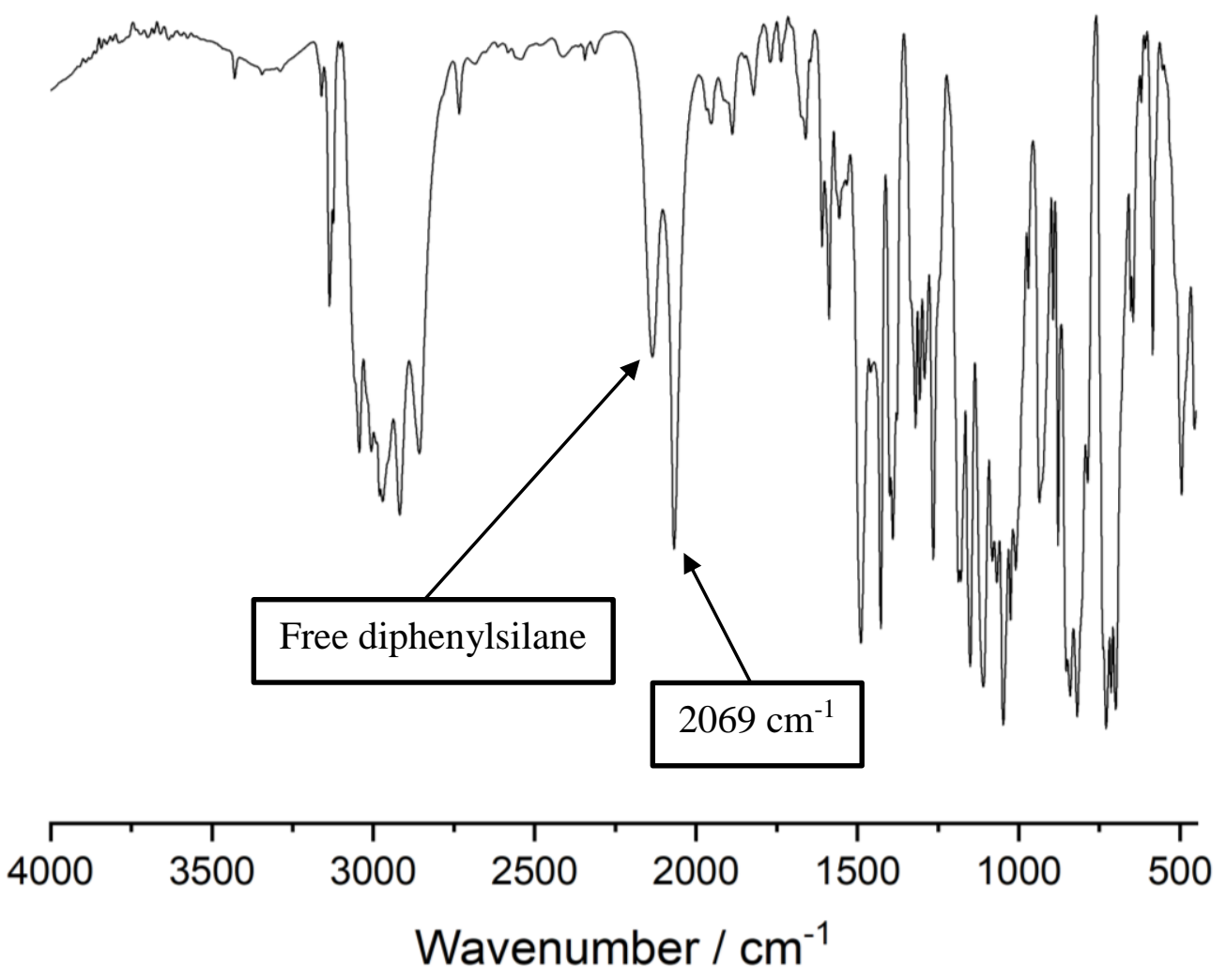

Figure S16. IR spectrum of $\mathbf{3}$ collected in $\mathrm{KBr}$ at $25^{\circ} \mathrm{C}$. 


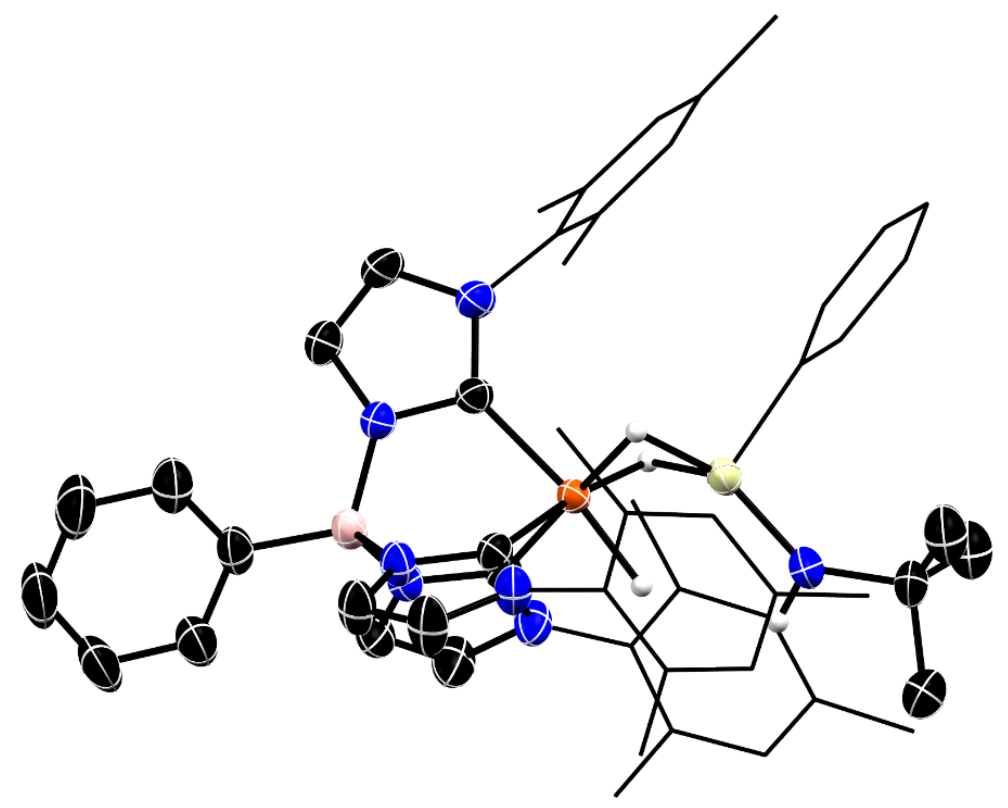

Figure S17. Molecular structure of 4 . Thermal ellipsoids are shown at 50\% probability. Color scheme: C, black; N, blue; B, pink; Fe, orange; Si, yellow. Most $\mathrm{H}$ atoms and solvent molecules have been omitted for clarity. The Mes and $\mathrm{Ph}$ groups are shown with wireframe representation for clarity.

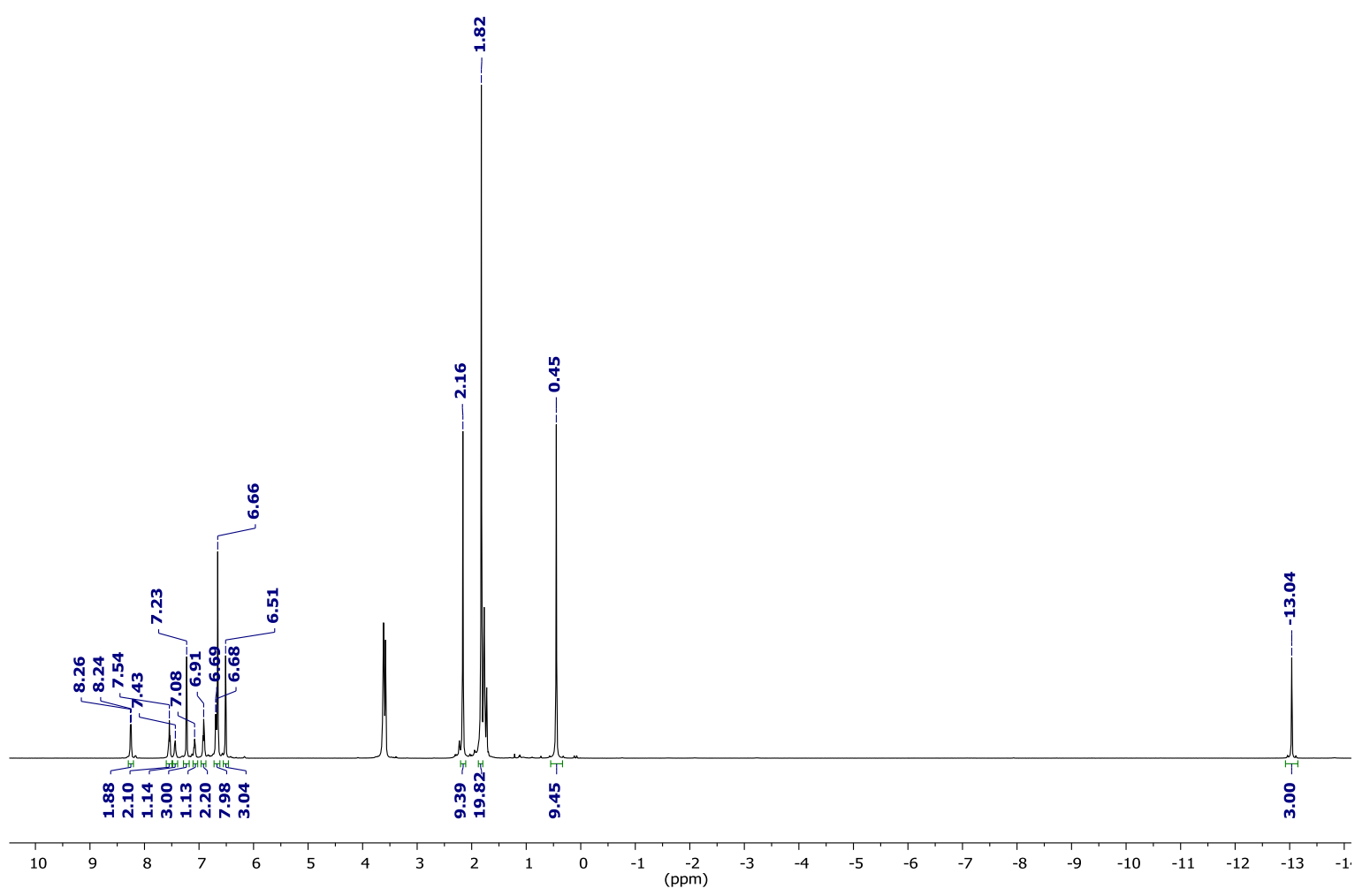

Figure S18. ${ }^{1} \mathrm{H}$ NMR (400 MHz, THF- $\left.d 8,25^{\circ} \mathrm{C}\right)$ of complex 4. 


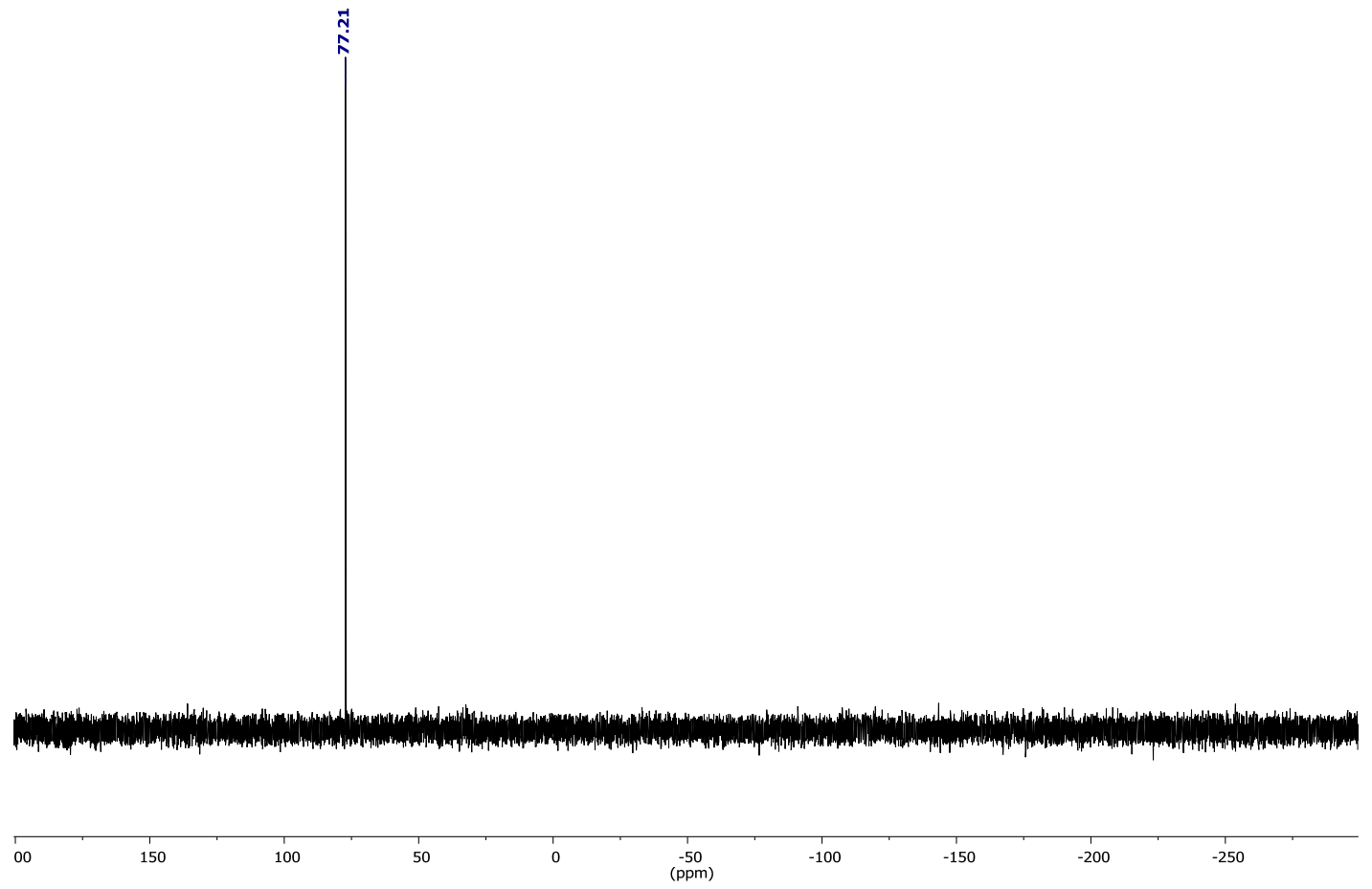

Figure S19. ${ }^{29} \mathrm{Si}\left\{{ }^{1} \mathrm{H}\right\}$ NMR $\left(99 \mathrm{MHz}, \mathrm{THF}-d_{8}, 25{ }^{\circ} \mathrm{C}\right)$ of complex 4.

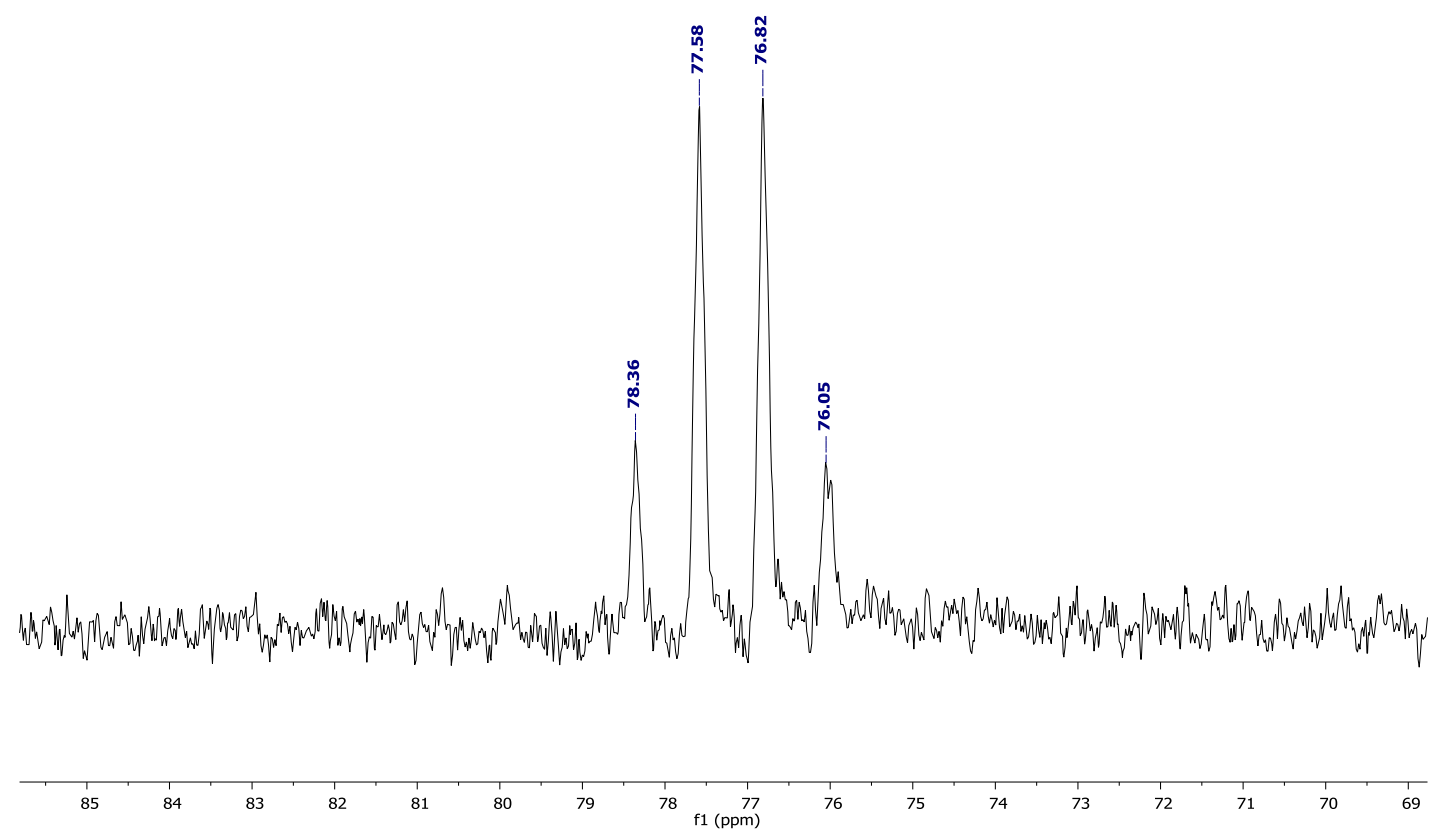

Figure S20. ${ }^{29} \mathrm{Si} \mathrm{NMR}\left(99 \mathrm{MHz}, \mathrm{THF}-d_{8}, 25^{\circ} \mathrm{C}\right)$ of complex 4. 


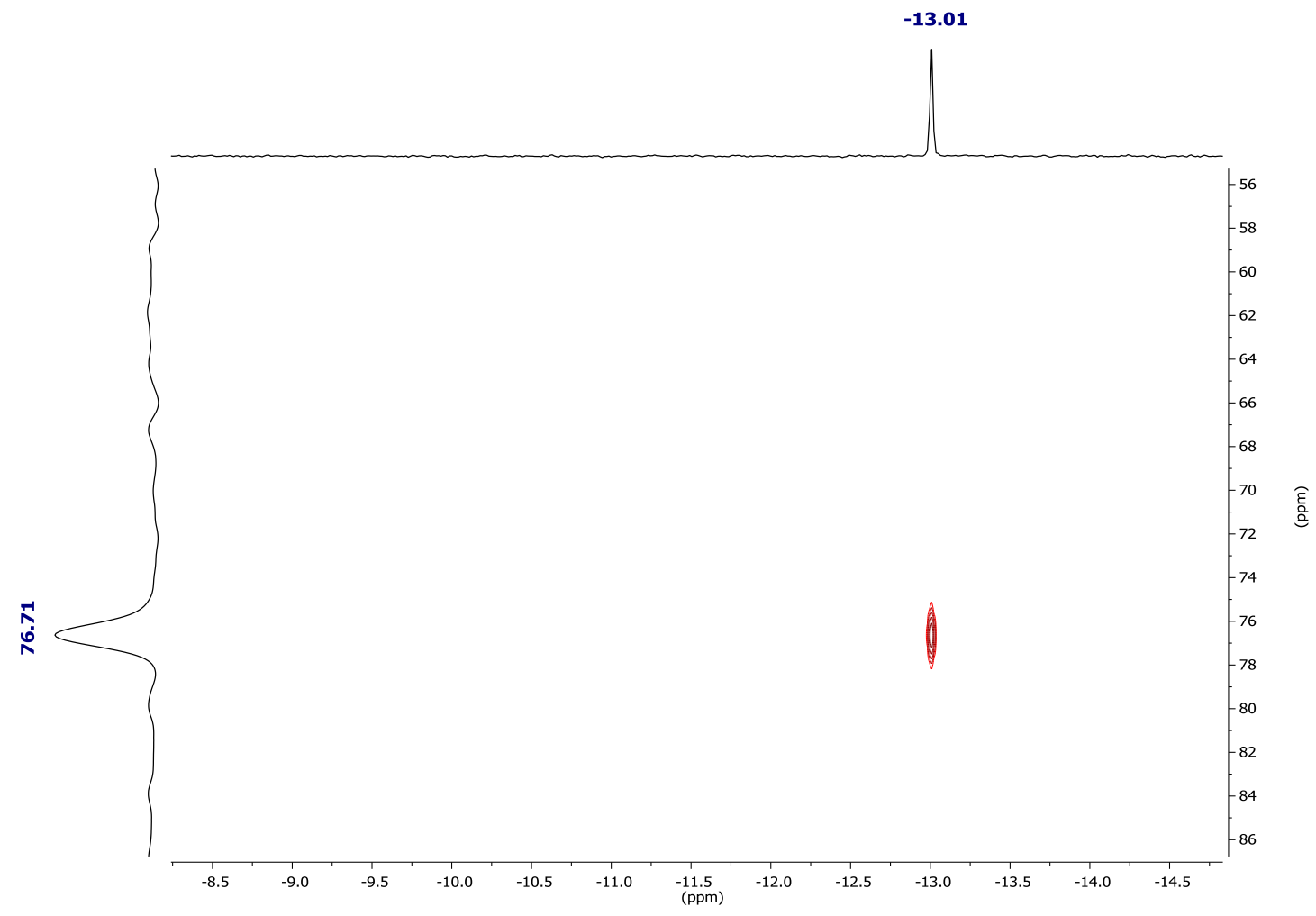

Figure S21. ${ }^{29} \mathrm{Si} /{ }^{1} \mathrm{H}$ HMQC $\left(99 \mathrm{MHz} / 500 \mathrm{MHz}, \mathrm{THF}-d_{8}, 25{ }^{\circ} \mathrm{C}\right)$ of 4.

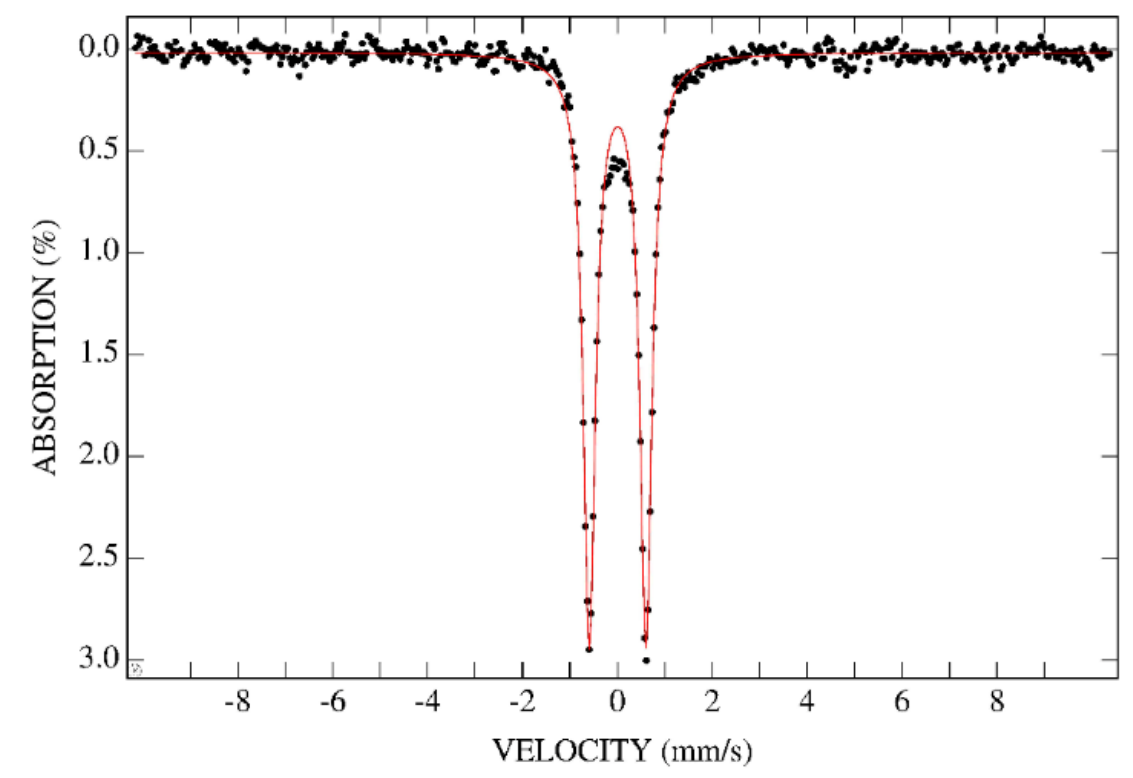

Figure S22. Mössbauer spectrum of 4 measured at $80 \mathrm{~K}$. Parameters: $\delta 0.00 \mathrm{~mm} \mathrm{~s}^{-1}, \Delta E_{\mathrm{Q}} 1.92$ $\mathrm{mm} \mathrm{s}^{-1}$ 


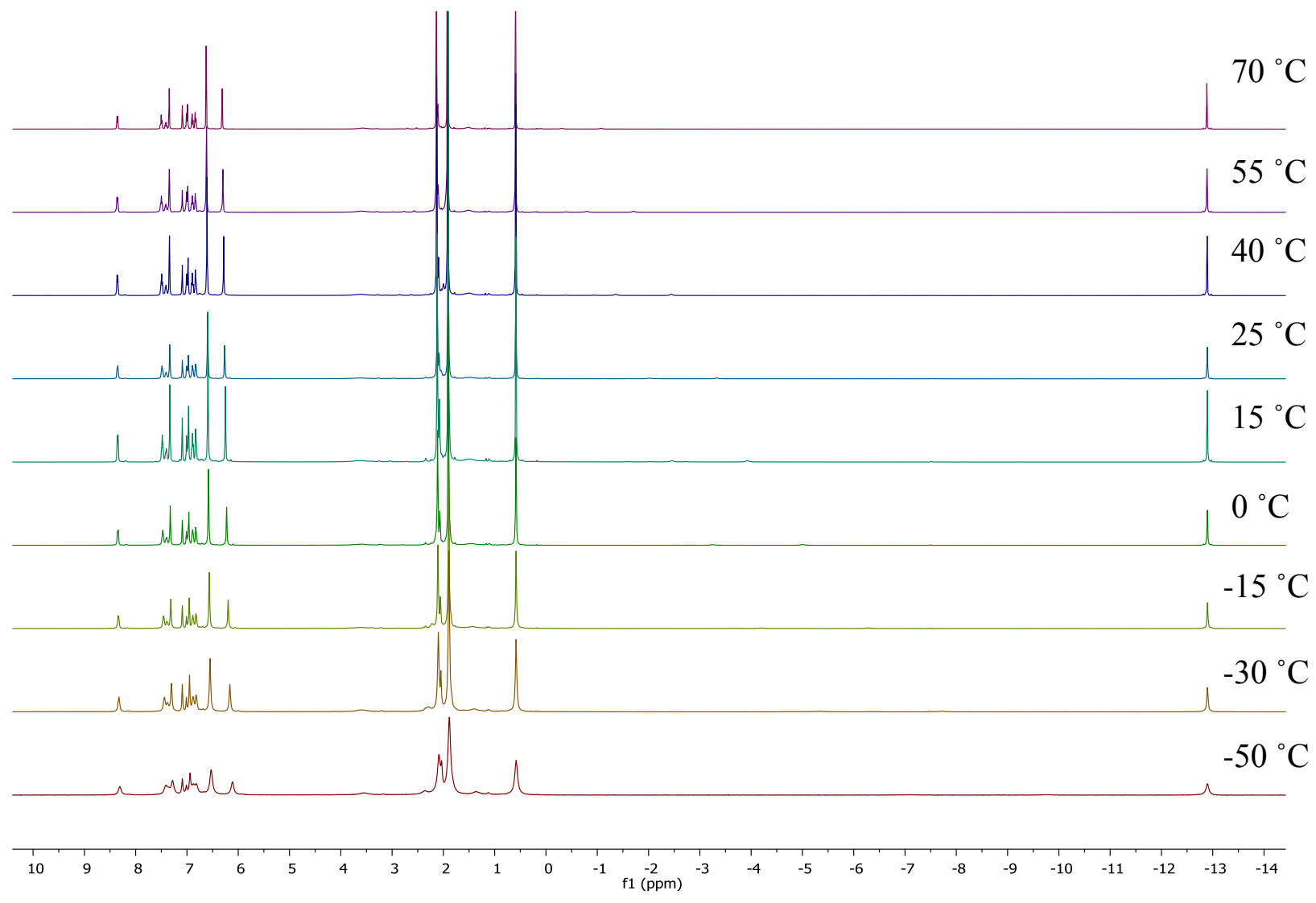

Figure S23. VT ${ }^{1} \mathrm{H}$ NMR spectra (400 MHz, Toluene- $d_{8}$ ) of 4.
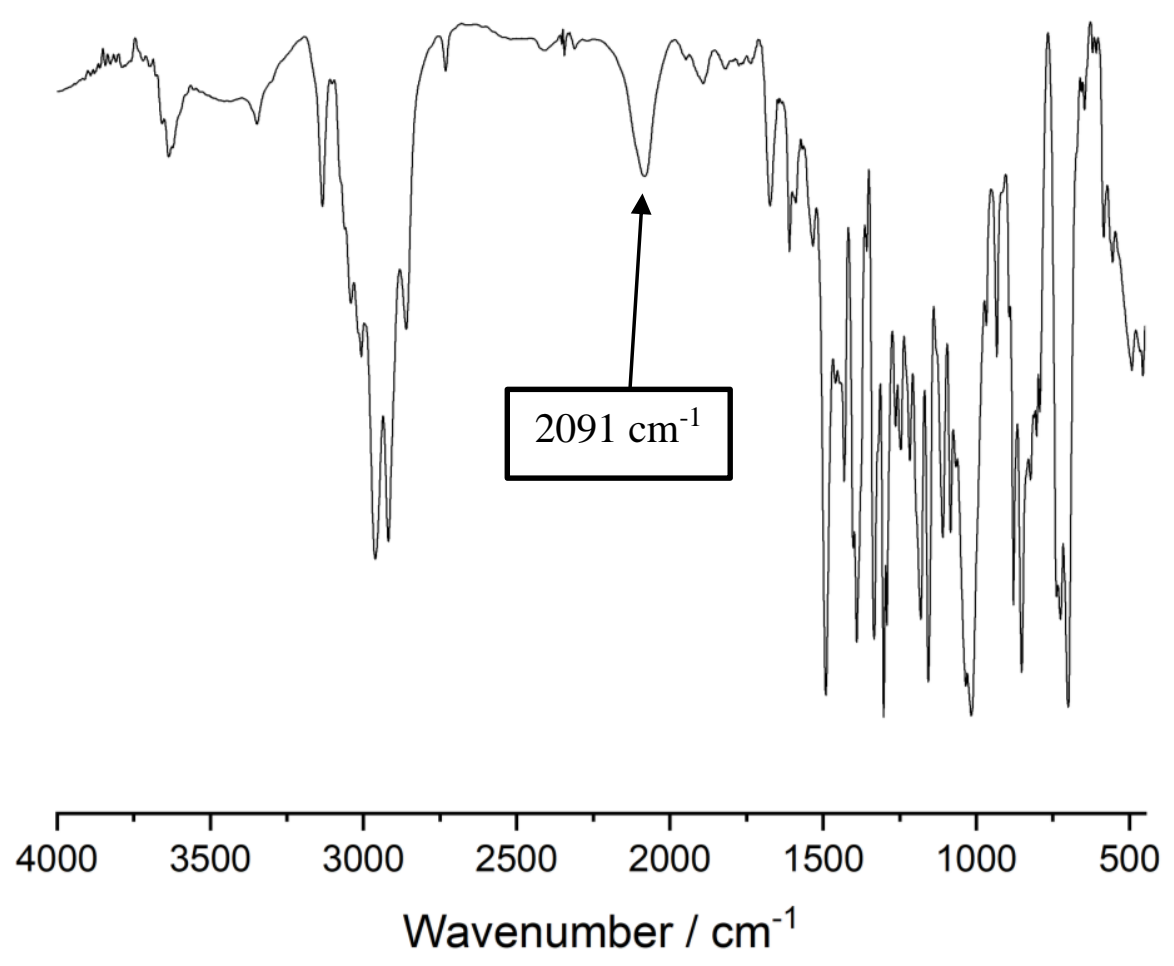

Figure S24. IR spectrum of 4 collected in $\mathrm{KBr}$ at $25{ }^{\circ} \mathrm{C}$. 


\section{Crystallographic Information}

\section{Data collection}

A single crystal was placed onto the tip of a MiTeGen pin and mounted on a Bruker Kappa Duo diffractometer equipped with a ApexII CCD detector at $173 \mathrm{~K}$. The data collection was carried out using Mo $\mathrm{K} \alpha$ radiation $(\lambda=0.71073 \AA$, graphite monochromator $)$ for PhB(MesIm) $)_{3} \mathrm{FeH}_{3} \mathrm{SiPhNH}^{\mathrm{t} B u}$ and $\mathrm{PhB}(\mathrm{MesIm})_{3} \mathrm{FeH}_{3} \mathrm{SiHPh}$, and $\mathrm{Cu} \mathrm{K} \alpha$ radiation $(\lambda=$ $1.54178 \AA$, graphite monochromator) for $\mathbf{P h B}(\mathbf{M e s I m})_{3} \mathbf{F e H}_{3} \mathbf{S i P h}_{2}$. The detector distance was 40 $\mathrm{mm}$. The exposure times were 10, 60 and 180 seconds for $\mathbf{P h B}(\mathbf{M e s I m})_{3} \mathbf{F e H} \mathbf{H}_{3} \mathbf{S i P h}_{2}$, PhB(MesIm) $)_{3} \mathrm{FeH}_{3} \mathrm{SiPhNH}^{\mathrm{t} B u}$ and $\mathrm{PhB}(\mathrm{MesIm})_{3} \mathrm{FeH}_{3} \mathrm{SiHPh}$, respectively. Data were collected to resolutions of $0.84, \quad 0.82$ and $0.84 \AA$ for $\mathbf{P h B}(\mathbf{M e s I m})_{3} \mathbf{F e H}_{3} \mathbf{S i P h}_{2}$, PhB(MesIm) $)_{3} \mathrm{FeH}_{3} \mathrm{SiPhNH}^{\mathrm{t} B u}$ and $\mathrm{PhB}(\mathrm{MesIm})_{3} \mathrm{FeH}_{3} \mathrm{SiHPh}$, respectively. The frames were integrated with the Bruker SAINT ${ }^{5}$ software package using a narrow-frame algorithm. Data were corrected for absorption effects using the Multi-Scan method (SADABS). ${ }^{6}$ Additional information is reported in Tables $\mathrm{S} 1-\mathrm{S} 4$.

\section{Structure solution and refinement}

The structures were solved using SUPERFLIP ${ }^{7}$ and refined using full-matrix least-squares on $\mathrm{F}^{2}$ within the CRYSTALS suite. ${ }^{8}$ A charge-flipping solution was calculated, which provided most non-hydrogen atoms from the E-map. Full-matrix least squares / difference Fourier cycles were performed, which located the remaining non-hydrogen atoms. All non-hydrogen atoms were refined with anisotropic displacement parameters. Hydrogen atoms were initially placed in ideal positions and refined with restraints on bond lengths and angles, after which the positions were used as the basis for a riding model. ${ }^{9}$ The bridging hydrogen atoms coordinated to the iron and silicon atom were obtained via the Fourier difference map, and then refined as riding.

Disorder on a phenyl ring was modelled for compound PhB(MesIm) ${ }_{3} \mathrm{FeH}_{3} \mathrm{SiPhNH}^{\mathbf{t} B u}$. The electron density was divided into two parts with 0.60 and 0.40 occupancies. Restraints on the bond lengths and angles were necessary, as well as vibrational and thermal similarity restraints. 
Table S1. Crystal structure information for PhB(MesIm)3FeH3SiHPh

Empirical formula

Formula weight

Crystal color, shape, size

Temperature

Wavelength

Crystal system, space group

Unit cell dimensions

Volume

Z

Density (calculated)

Absorption coefficient

$\mathrm{F}(000)$

Data collection

Diffractometer

Theta range for data collection

Index ranges

Reflections collected

Independent reflections

Observed Reflections

Completeness to theta $=25.796^{\circ}$

Solution and Refinement

Absorption correction

Max. and min. transmission

Solution

Refinement method

Weighting scheme

Data / restraints / parameters

Goodness-of-fit on $\mathrm{F}^{2}$

Final $R$ indices $[\mathrm{I}>2 \sigma(\mathrm{I})]$

$\mathrm{R}$ indices (all data)

Largest diff. peak and hole

\section{C52 H63 B1 Fe1 N6 O1 Si1}

882.86

red block, $0.200 \times 0.200 \times 0.100 \mathrm{~mm}^{3}$

$173 \mathrm{~K}$

$0.71073 \AA$

Monoclinic, $\mathrm{P} 2 \mathrm{1} / \mathrm{n}$

$\mathrm{a}=14.2044(8) \AA \alpha=90^{\circ}$.

$\mathrm{b}=19.1368(12) \AA \beta=91.894(2)^{\circ}$.

$\mathrm{c}=17.6250(11) \AA \gamma=90^{\circ}$.

4788.3(5) $\AA^{3}$

4

$1.225 \mathrm{Mg} / \mathrm{m}^{3}$

$0.384 \mathrm{~mm}^{-1}$

1880

Kappa Apex II Duo, Bruker

1.786 to $25.032^{\circ}$.

$-16<=\mathrm{h}<=12,-19<=\mathrm{k}<=22,-20<=\mathrm{l}<=18$

25757

8199 [Rint $=0.069]$

4962

$96.9 \%$

Semi-empirical from equivalents

0.96 and 0.93

Intrinsic methods

Full-matrix least-squares on $\mathrm{F}^{2}$

$\mathrm{w}=\left[\sigma^{2} \mathrm{Fo}^{2}+\mathrm{AP}^{2}+\mathrm{BP}\right]^{-1}$, with

$\mathrm{P}=\left(\mathrm{Fo}^{2}+2 \mathrm{Fc}^{2}\right) / 3, \mathrm{~A}=0.017, \mathrm{~B}=9.490$

$8160 / 0 / 559$

1.0072

$\mathrm{R} 1=0.0679, \mathrm{wR} 2=0.1538$

$\mathrm{R} 1=0.1224, \mathrm{wR} 2=0.1840$

1.35 and -0.81 e. $\AA^{-3}$ 
Table S2. Crystal structure information for PhB(MesIm)3FeNHSiHPh2.

Empirical formula

Formula weight

Crystal color, shape, size

Temperature

Wavelength

Crystal system, space group

Unit cell dimensions

Volume

Z

Density (calculated)

Absorption coefficient

$\mathrm{F}(000)$

Data collection

Diffractometer

Theta range for data collection

Index ranges

Reflections collected

Independent reflections

Observed Reflections

Completeness to theta $=25.796^{\circ}$

Solution and Refinement

Absorption correction

Max. and min. transmission

Solution

Refinement method

Weighting scheme

Data / restraints / parameters

Goodness-of-fit on $\mathrm{F}^{2}$

Final $R$ indices $[\mathrm{I}>2 \sigma(\mathrm{I})]$

$\mathrm{R}$ indices (all data)

Largest diff. peak and hole
C54 H56 B1 Fe1 N7 Si1

897.83

pale yellow plate, $0.300 \times 0.150 \times 0.100 \mathrm{~mm}^{3}$

$173 \mathrm{~K}$

$0.71073 \AA$

Monoclinic, $\mathrm{P} 21 / \mathrm{n}$

$\mathrm{a}=15.48710(4) \AA \alpha=90^{\circ}$.

$\mathrm{b}=19.03810(4) \AA \beta=97.079(4)^{\circ}$.

$\mathrm{c}=16.66460(4) \AA \gamma=90^{\circ}$.

4876.02(4) $\AA^{3}$

4

$1.223 \mathrm{Mg} / \mathrm{m}^{3}$

$0.377 \mathrm{~mm}^{-1}$

1895.999

Kappa Apex II Duo, Bruker

1.631 to $26.594^{\circ}$.

$-19<=\mathrm{h}<=18,-23<=\mathrm{k}<=22,-20<=\mathrm{l}<=20$

51202

$9993[$ Rint $=0.096]$

6038

$99.5 \%$

Semi-empirical from equivalents

1.00 and 0.79

Intrinsic methods

Full-matrix least-squares on $\mathrm{F}^{2}$

$\mathrm{w}=\left[\sigma^{2} \mathrm{Fo}^{2}+\mathrm{AP}^{2}+\mathrm{BP}\right]^{-1}$, with

$\mathrm{P}=\left(\mathrm{Fo}^{2}+2 \mathrm{Fc}^{2}\right) / 3, \mathrm{~A}=, \mathrm{B}=$

9977 / 136 / 633

1.3600

$\mathrm{R} 1=0.0633, \mathrm{wR} 2=0.1221$

$\mathrm{R} 1=0.1109, \mathrm{wR} 2=0.1517$

0.68 and -1.22 e. $\AA^{-3}$ 
Table S3. Crystal structure information for $\mathrm{PhB}(\mathrm{MesIm})_{3} \mathrm{FeH}_{3} \mathrm{SiPh}_{2}$

Empirical formula

Formula weight

Crystal color, shape, size

Temperature

Wavelength

Crystal system, space group

Unit cell dimensions

Volume

$\mathrm{Z}$

Density (calculated)

Absorption coefficient

$\mathrm{F}(000)$

Data collection

Diffractometer

Theta range for data collection

Index ranges

Reflections collected

Independent reflections

Observed Reflections

Completeness to theta $=25.796^{\circ}$

Solution and Refinement

Absorption correction

Max. and min. transmission

Solution

Refinement method

Weighting scheme

Data / restraints / parameters

Goodness-of-fit on $\mathrm{F}^{2}$

Final $\mathrm{R}$ indices $[\mathrm{I}>2 \sigma(\mathrm{I})]$

$\mathrm{R}$ indices (all data)

Largest diff. peak and hole

\section{C54 H57 B1 Fe1 N6 Si1}

884.83

red plate, $0.27 \times 0.21 \times 0.06 \mathrm{~mm}^{3}$

$173 \mathrm{~K}$

$1.54178 \AA$

Monoclinic, $\mathrm{P} 21 / \mathrm{n}$

$\mathrm{a}=11.62620(2) \AA \alpha=90^{\circ}$.

$\mathrm{b}=28.44390(3) \AA \beta=108.327(2)^{\circ}$.

$\mathrm{c}=14.89020(2) \AA \gamma=90^{\circ}$.

4674.34(7) $\AA^{3}$

4

$1.257 \mathrm{Mg} / \mathrm{m}^{3}$

$3.161 \mathrm{~mm}^{-1}$

1872

Kappa Apex II Duo, Bruker

3.107 to $66.595^{\circ}$.

$-13<=\mathrm{h}<=12,-33<=\mathrm{k}<=33,-17<=\mathrm{l}<=17$

95413

$8231[$ Rint $=0.047]$

6977

$99.6 \%$

Semi-empirical from equivalents

1.00 and 0.72

Intrinsic methods

Full-matrix least-squares on $\mathrm{F}^{2}$

$\mathrm{w}=\left[\sigma^{2} \mathrm{Fo}^{2}+\mathrm{AP}^{2}+\mathrm{BP}\right]^{-1}$, with

$\mathrm{P}=\left(\mathrm{Fo}^{2}+2 \mathrm{Fc}^{2}\right) / 3, \mathrm{~A}=0.045, \mathrm{~B}=2.465$

$8231 / 7$ / 568

0.9975

$\mathrm{R} 1=0.0371, \mathrm{wR} 2=0.0886$

$\mathrm{R} 1=0.0464, \mathrm{wR} 2=0.0937$

0.29 and -0.37 e. $\AA^{-3}$ 
Table S4. Crystal structure information for $\mathbf{P h B}(\mathrm{MesIm})_{3} \mathrm{FeH}_{3} \mathrm{SiPhNH}^{\mathrm{t} B u}$

Empirical formula

Formula weight

Crystal color, shape, size

Temperature

Wavelength

Crystal system, space group

Unit cell dimensions

Volume

$\mathrm{Z}$

Density (calculated)

Absorption coefficient

$\mathrm{F}(000)$

Data collection

Diffractometer

Theta range for data collection

Index ranges

Reflections collected

Independent reflections

Observed Reflections

Completeness to theta $=25.796^{\circ}$

Solution and Refinement

Absorption correction

Max. and min. transmission

Solution

Refinement method

Weighting scheme

Data / restraints / parameters

Goodness-of-fit on $\mathrm{F}^{2}$

Final $R$ indices $[\mathrm{I}>2 \sigma(\mathrm{I})]$

$\mathrm{R}$ indices (all data)

Largest diff. peak and hole
C57.50 H74.50 B1 Fe1 N7 O1.25 Si1.50

992.56

yellow plate, $0.460 \times 0.220 \times 0.190 \mathrm{~mm}^{3}$

$173 \mathrm{~K}$

$0.71073 \AA$

Monoclinic, $\mathrm{P} 21 / \mathrm{n}$

$\mathrm{a}=15.56290(3) \AA \alpha=90^{\circ}$.

$\mathrm{b}=18.17000(3) \AA \beta=104.354(3)^{\circ}$.

$\mathrm{c}=22.57180(3) \AA \gamma=90^{\circ}$.

6183.54(8) $\AA^{3}$

4

$1.066 \mathrm{Mg} / \mathrm{m}^{3}$

$0.314 \mathrm{~mm}^{-1}$

2122

Kappa Apex II Duo, Bruker

1.351 to $25.682^{\circ}$.

$-18<=\mathrm{h}<=18,-16<=\mathrm{k}<=22,-26<=\mathrm{l}<=27$

36507

$11686[$ Rint $=0.033]$

8099

$99.5 \%$

Semi-empirical from equivalents

1.00 and 0.83

Intrinsic methods

Full-matrix least-squares on $\mathrm{F}^{2}$

$\mathrm{w}=\left[\sigma^{2} \mathrm{Fo}^{2}+\mathrm{AP}^{2}+\mathrm{BP}\right]^{-1}$, with

$\mathrm{P}=\left(\mathrm{Fo}^{2}+2 \mathrm{Fc}^{2}\right) / 3, \mathrm{~A}=0.106, \mathrm{~B}=15.415$

$11655 / 1353 / 753$

0.9658

$\mathrm{R} 1=0.0737, \mathrm{wR} 2=0.2167$

$\mathrm{R} 1=0.1046, \mathrm{wR} 2=0.2401$

1.25 and -0.62 e. $\AA^{-3}$ 


\section{References}

1. Scepaniak, J. J.; Young, J. A.; Bontchev, R. P.; Smith, J. M. "Formation of Ammonia from an Iron Nitrido Complex" Angew. Chem. Int. Ed. 2009, 48, 3158-3160.

2. Nieto, I.; Ding, F.; Bontchev, R. P.; Wang, H.; Smith, J. M. "Thermodynamics of Hydrogen Atom Transfer to a High-Valent Iron Imido Complex" J. Am. Chem. Soc. 2008, 130, 2716-2717.

3. Tay, B.-Y.; Wang, C.; Stubbs, L. P.; Jacob, C.; van Meurs, M. "Deuterated dimethyl sulfoxide as a good NMR solvent for the characterization of alkali metal cyclopentadienides, amides, alkoxides and phenoxides" J. Organomet. Chem. 2011, 696, 3431-3435.

4. Prisecaru, I. WMOSS4 Mössbauer Spectral Analysis Software, www.wmoss.org, 2009-2016.

5. SAINT, Bruker Analytical X-Ray Systems, Current Version; Madison, WI.

6. $\quad$ SADABS, Bruker Analytical X-Ray Systems, Current version; Madison, WI.

7. Palatinus, L.; Chapuis, G. "SUPERFLIP - a computer program for the solution of crystal structures by charge flipping in arbitrary dimensions" J. Appl. Crystallogr. 2007, 40, 786-790.

8. Betteridge, P. W.; Carruthers, J. R.; Cooper, R. I.; Prout, K.; Watkin, D. J. "CRYSTALS version 12: software for guided crystal structure analysis" J. Appl. Crystallogr. 2003, 36, 1487.

9. Cooper, R. I.; Thompson, A. L.; Watkin, D. J. "CRYSTALS enhancements: dealing with hydrogen atoms in refinement" J. Appl. Crystallogr. 2010, 43, 1100-1107. 